\title{
The Changing Nature of Employment Discrimination Litigation
}

\author{
John J. Donohue III* \\ Peter Siegelman**
}

The future of America's policy towards civil rights in employment will be determined by the current battle between two opposing forces. One group sees the expansion of federal power to eliminate employment discrimination as the product of this country's growing commitment to racial and gender justice. Its champion is the United States Congress, and its weapon of choice is the Civil Rights Act of 1991. Another group sees the mounting costs of the voluminous litigation over employment discrimination as a drain on business well past the point of diminishing returns. It hopes that the United States Supreme Court will relax or trim federal civil rights law. The outcome of this confrontation is as yet unsettled, and in the near future we may be left with substantially the same policy that has been in place over the last fifteen years or so, a more stringent antidiscrimination regime, or a more pallid one.

Unfortunately, much of the debate over the future of civil rights in employment has been characterized by high ratios of rhetoric to fact. The battle has frequently been ideological, with both camps unaware of many of the essential characteristics of employment discrimination litigation. Indeed, both seem to view such litigation as though it still operated as it did when Title VII of the 1964 Civil Rights Act first took effect.

The nature of employment discrimination litigation in the federal courts, however, has changed considerably since Title VII went into effect twentysix years ago. This paper focuses on the causes and consequences of three major changes. First, the volume of federal employment discrimination liti-

* Professor of Law, Northwestern University School of Law; Research Fellow, American Bar Foundation.

** Research Fellow, American Bar Foundation. We would like to thank the Fund for Labor Relations Studies and the American Bar Foundation for funding. This paper has seen numerous drafts and has drawn on an unusually large number of people for assistance. We have been greatly aided by the able work of Theresa Beiner, Jeffrey Bloom, Joe Comprix, Darwin Farrar, Jeffrey Hummel, Dawn Jeglum-Bartusch, Sam Miller, John Murphy, Kirsten Alesch Muth, Brian Sheehan, Daniel Shiman, Robert Taylor, Sharon Tennyson, and Jianxin Wang. We received many useful comments from Ian Ayres, Paul Burstein, David Cook, Mayer Freed, James Heckman, Alan Krueger, Mitch Polinsky, and Stewart Schwab, as well as from participants in workshops at the Law and Society Association, Columbia Law School, the University of Virginia Law School, the University of Chicago Law School, the Department of Economics at the University of Illinois at Chicago, the University of Pennsylvania Law School, the University of California at Berkeley, Stanford Law School, and Cornell Law School. 
gation has grown spectacularly, many times faster than the overall federal civil caseload. Indeed, the growth has been so rapid as to raise concern that employment discrimination cases now impose a significant burden on federal judges. ${ }^{1}$ The sheer increase in the number of cases filed by itself requires a qualitative change in our understanding of employment discrimination law. Second, the composition of litigation has shifted dramatically: While most cases formerly attacked discrimination in hiring, today the vast majority of all litigation suits challenge discrimination in discharge. Although the authors and early architects of employment discrimination laws envisioned them as tools for opening employment opportunities to blacks, women, and other minorities, this is no longer their primary use. Instead, the antidiscrimination laws are predominantly used to protect the existing positions of incumbent workers. The third major change in the nature of employment discrimination litigation is the decline of the class action. While individual suits have blossomed, the class action, once a key aspect of the fight for civil rights in the work place, has withered, with only fifty-one employment discrimination class actions filed in Fiscal Year (FY) 1989.2

These changes, which we document in greater detail below, pose two sets of challenges. Initially we seek explanations for the phenomena. Why has the number of suits grown so rapidly? Can we attribute the increase to a broadening of plaintiffs' rights, or was it caused by exogenous socioeconomic factors such as the long run increase in unemployment rates? What accounts for the changing composition of litigation-why is discharge (rather than hiring) now the leading type of discrimination complained about in litigation? Why have class actions virtually vanished from the landscape of employment discrimination disputes?

Beyond explanations, these observations suggest a need for reevaluating employment discrimination policy. Ideally, the policy should generate the appropriate volume and composition of litigation in order both to provide an adequate deterrent for employers considering discriminatory practices and to compensate victims of discrimination. We must explore whether the current private enforcement regime suitably furthers these objectives.

Part I analyzes several socioeconomic and legal changes that may have prompted the rise in employment discrimination litigation and estimates that these factors account for roughly two-thirds of the growth in litigation. Part II attempts to explain the residual growth. After discussing a number of commonly offered explanations, we put forth a somewhat counterintuitive theory of our own: As minorities and women moved into better jobs and the work place became more integrated, the likelihood of certain kinds of em-

1. See Federal Courts Study Committee, Tentative Recommendations for Public COMMENT 49-50 (1989) (noting the increase in employment discrimination cases and recommending that the EEOC be authorized under a test program to adjudicate wrongful discharge cases, thus reducing the caseload of federal courts).

2. Administrative Office of the U.S. Courts, Computer File (1989) (on file with the authors) [hereinafter Admin. Off. File]. For a more detailed description of the computer file, see note 3 infra. Moreover, only a small percentage of these 51 cases will actually be certified as class actions. See Figure 8 infra. 
ployment discrimination litigation increased. Part III analyzes the shifting composition of employment discrimination litigation-from discriminatory hiring to discriminatory discharge, and from class actions to individual suits. Finally, the conclusion discusses some policy implications of our findings.

\section{The Growth IN Volume of Employment DISCRIMINATION CASES}

\section{A. Distinguishing Long-Term Trends from Cyclical Fluctuations}

As Figure 1 illustrates, the volume of employment discrimination litigation has grown substantially over the last twenty years-from less than 350 cases filed per year in FY 1970 to a peak of about 9,000 in FY 1983. Figure 2 compares the pattern of employment discrimination filings with all other federal civil litigation and reveals two phenomena: First, employment discrimination case filings have grown far faster than the general federal civil caseload, which rose by only about 125 percent between FY 1970 and FY 1989 , as compared with the 2166 percent growth in the employment discrimination caseload; and second, the variation around the general upward trend is far greater for employment discrimination cases than for the general civil caseload. ${ }^{3}$ In other words, the volume of employment discrimination cases filed has grown much more rapidly than the overall civil caseload, but this growth has also been much more erratic, with periods of substantial decline and spurts of exceptional growth.

Any attempt to understand what determines the volume of employment discrimination litigation must distinguish between causes of long-run trend growth and causes of short-run fluctuations around this trend. For example, long-run growth in the volume of cases may be due to the steady increases in the population of "protected workers" covered by antidiscrimination laws or

3. The litigation data used in this paper come largely from three sources. First, data on the volume of employment discrimination suits filed are from Admin. Off. File, supra note 2. The computer tape includes all suits classified by the Administrative Office as "Civil Rights, Employment" (code no. 442) filed between July 1969 and June 1989. The "Civil Rights, Employment" category encompasses cases brought under Title VII (roughly $80 \%$ of the total), the Age Discrimination in Employment Act (ADEA), the Equal Pay Act (EPA), the Rehabilitation Act, and $\S \S 1981$ and 1983. The tape also includes some cases that we would not classify as employment discrimination cases, such as those asserting due process claims by public employees. About $10 \%$ of the cases on the computer tape are either duplicate docket numbers (with similar or identical plaintiff and defendant names and filing dates) or non-original jurisdiction cases. We deleted these cases from our data set. For further details on this data and the procedures used to clean it up, see Peter Siegelman, An Economic Analysis of Employment Discrimination Litigation (May 1991) (unpublished dissertation) (on file with the Stanford Law Review).

Second, data on EEOC charges come from the EEOC's annual reports for the Fiscal Years 1966 through 1985. 1966-1985 EEOC ANN. REP. [hereinafter EEOC].

Finally, the American Bar Foundation Employment Discrimination Litigation Survey, Computer File (1990) (on file with the authors) [hereinafter ABF Survey], contains the results of a detailed study of some 1250 employment discrimination cases in 7 cities (Atlanta, Chicago, Dallas, New Orleans, New York, Philadelphia, and San Francisco). Over the period from 1972 to 1987, just under $20 \%$ of all federal employment discrimination cases were filed in these seven cities. Although the cities were not selected randomly, the sample of cases chosen was randomly drawn from all cases filed in these cities between 1972 and 1987. We believe that the sample of cities contains enough internal variation to make it a useful, albeit imperfect, proxy for the U.S. caseload as a whole. 
Figure 1

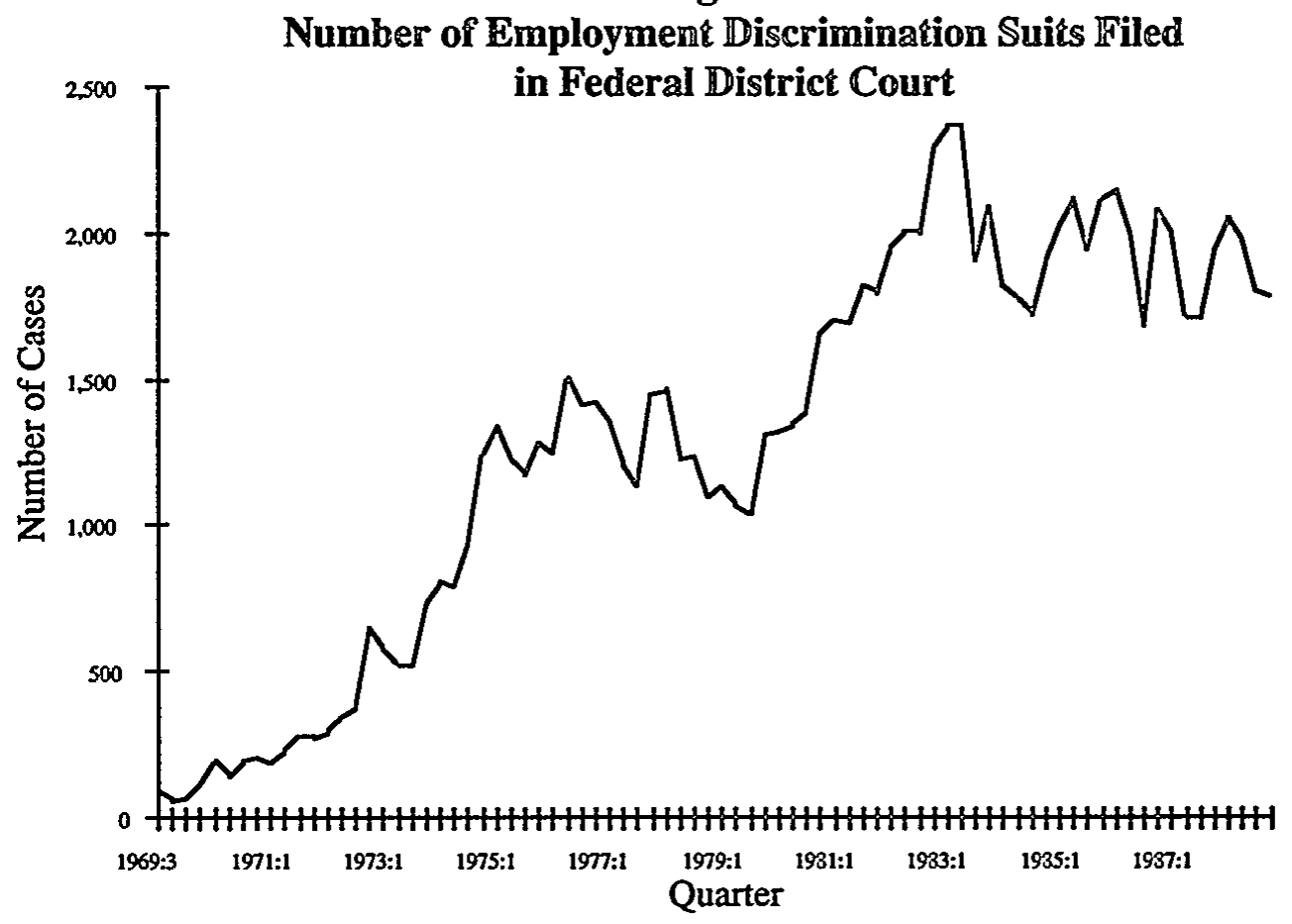

Sources: Administrative Office of the U.S. Courts, Computer File (1989) (on file with the authors).

Figure 2

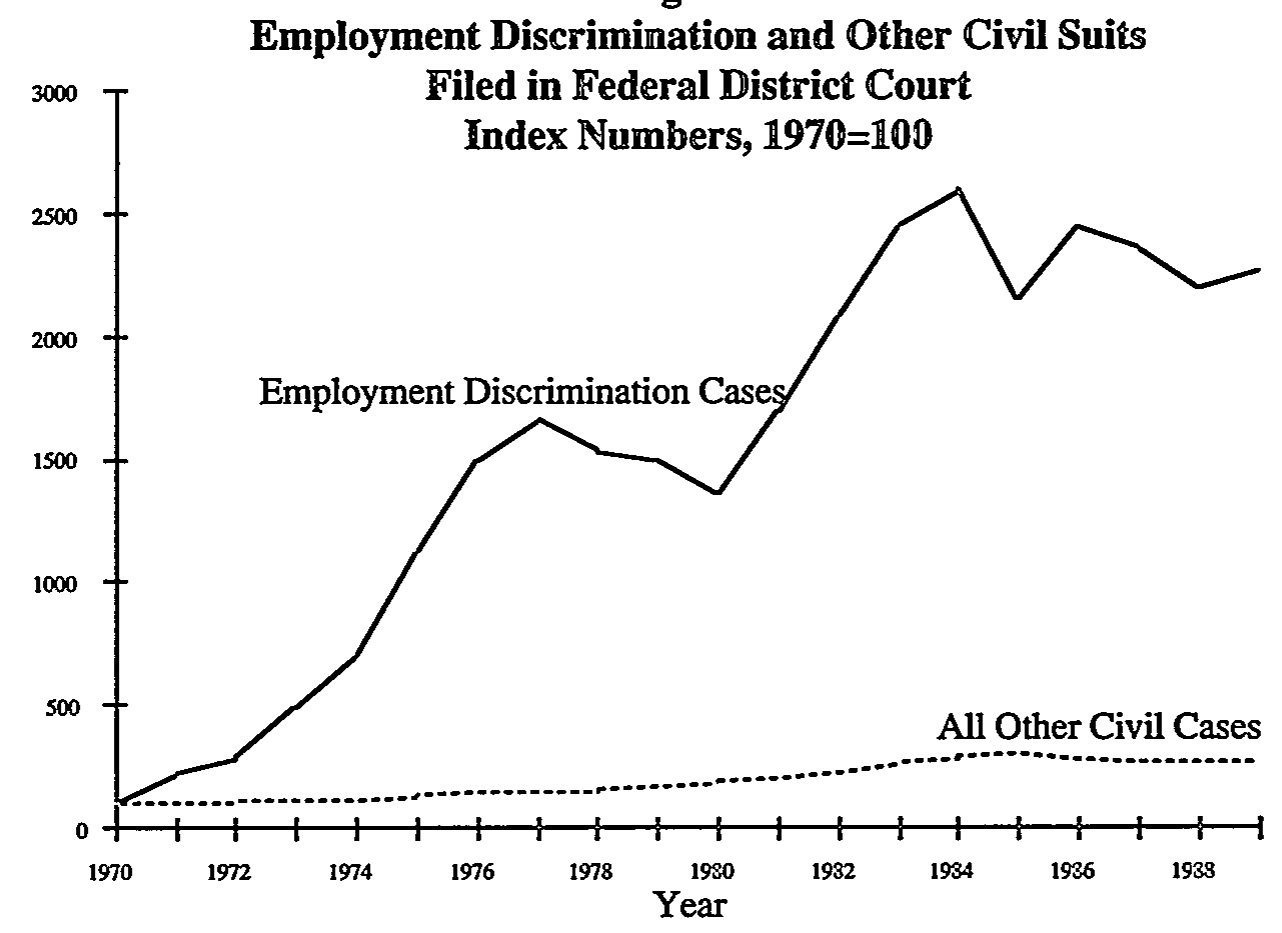

Sources: Administrative Office of the U.S. Courts, Computer File (1989) (on file with the authors). 
to the gradual dissemination of information on how the law operates. Shortrun fluctuations in the volume of cases might correspond to fluctuations in economic output-that is, to macroeconomic recessions and booms. The equation in Table 1 presents a simple way of quantifying this distinction by regressing the quarterly volume of employment discrimination cases filed in federal district courts on a time trend (TIME and TIME ${ }^{2}$ ) and lagged values of the unemployment rate (UNEM-1 and UNEM -2 ). The estimated coefficient on the time trend is meant to capture the average growth in the volume of cases while holding the state of the economy constant; the coefficient on the unemployment rate shows how the volume of cases responds to ups and downs in economic activity. Table 1 reports the results from our regression. ${ }^{4}$

Table 1

Maximum Likelihood Estimates of Quarterly Volume of Employment Discrimination Cases (Corrected for Autocorrelated Disturbances)

$$
\begin{aligned}
\text { CASES }= & -692.5+28.7\left(\mathrm{TIME}_{\mathrm{TM}}\right)-0.09\left(\mathrm{TMME}^{2}\right)+102.9\left(\mathrm{UNEM}_{-1}\right)+48.3\left(\mathrm{UNEM}_{-2}\right) \\
(-5.63)(4.32) & (-1.14)
\end{aligned}
$$

Adjusted $\mathrm{R}^{2}=0.96$

Durbin-Watson $=1.97$

Rho-hat $=0.63$

Standard Error $=147.9$

T-Statistics are in parentheses

Number of observations $=80$

The coefficients on the TIME and TIME ${ }^{2}$ variables suggest that employment discrimination cases increase at an underlying trend rate of 344 cases per year. ${ }^{5}$ It must be emphasized that the time trend only measures any persistent upward (or downward) movement in the number of cases filed, and does not identify the cause of the observed trend. The significant coefficients on the lagged unemployment rates reveal that a decrease of one percentage point in the unemployment rate would cause the number of case filings to fall by roughly 103 in the next quarter and by 48 in the following

4. Data on the volume of litigation comes from Admin. Off. File, supra note 2. Unemployment figures are from the U.S. DEPARTMENT OF COMMERCE, SURVEY OF CURRENT BUSINESS (19701990). Note that the time variable is measured in quarter years beginning with the third quarter of 1969 and proceeding for the next 20 years. Siegelman, supra note 3, contains more elaborate empirical models of the volume of litigation and details how the correction for autocorrelated errors was made.

5. The presence of $\mathrm{TIME}^{2}$ in the equation makes the effect of an increase in time non-linear. The effect was calculated at the mean value of time-that is, half-way through the 20-year sample, at quarter 40. To estimate the average effect of a quarter-year increase in time, take

$$
(28.7 \times 1)-\left[0.09 \times\left(40.5^{2}-39.5^{2}\right)\right]=28.7-7.2=21.5
$$

additional suits per quarter. Note that to convert the coefficients (measured in units of suits/quar$\left.t^{2}{ }^{2}\right)$ to an annual base, one multiplies by 16 (e.g., $21.5 \times 16=344$ ). Observe also that only the TIME coefficient, and not that on TIME ${ }^{2}$, is significantly different from zero at the $5 \%$ level. 
quarter. In other words, good economic conditions will lead to fewer employment discrimination lawsuits, presumably because the greater availability of alternative employment serves as an attractive alternative to litigation. Also, the relative scarcity of workers will diminish the likelihood of employment discrimination, and with fewer layoffs, there will be fewer aggrieved workers who might pursue actions against former employers. ${ }^{6}$

The explanatory power of the regression, as measured by its $R^{2}$ coefficient, is quite high, even for a time-series estimate: 96 percent of the variance in the number of suits filed is explained by the time trend and the lagged unemployment rates. The relatively sparse model of Table 1 therefore serves the useful functions of both approximating the size of the underlying growth rate in the number of employment discrimination cases and explaining the variation around this upward trend.

\section{B. Decomposing the Long-Term Trend Growth in Employment Discrimination Litigation}

Thus far we have demonstrated the existence of a positive time trend in the volume of litigation and briefly discussed why the number of employment discrimination cases bounces around this long-term trend. But we have not yet offered any explanation for the existence of the trend itself. This section attempts to quantify the importance of several factors that are likely to have played a role in the growth of employment discrimination litigation. Our results are summarized in Table 2 and are discussed at greater length below. ${ }^{7}$ Before we consider this table, we should point out that it represents an extremely rough attempt to assess the sources of growth in litigation. It uses data from a number of different sources that are not necessarily compatible. Moreover, it is not a statistical procedure such as regression analysis that can be subjected to significance tests. Therefore, one should view the table simply as an extended "back-of-the-envelope" calculation designed to assign an order of magnitude to the various effects we consider.

In Table 2 we draw a distinction between "legal or policy" and "economic or demographic" sources of growth in the employment discrimination caseload. Such a distinction is necessarily somewhat artificial. Nevertheless, we make it in order to highlight a fundamental difference between the sources of growth in litigation. Litigation prompted by new laws, changes in judicial interpretation of statutes, or governmental decisions to bring suit is subject to control by policy makers. In contrast, litigation arising from exogenous events such as changes in the size of the labor force or a rise in the

6. For further discussion, see Peter Siegelman \& John J. Donohue, The Behavior of Employment Discrimination Litigation Over the Business Cycle (1991) (unpublished manuscript) (on file with the Stanford Law Review).

7. The methodology is loosely based on the growth accounting techniques of Denison. See EDWARd F. DENISON, THE SOURCES OF ECONOMIC GROWTH IN THE UNITED STATES AND the ALTERNATIVES BEFORE Us (1962). 
Table 2

Sources of Growth in the Volume of Federal

Employment Civil Rights Cases, 1970-1989

1. Number of Employment Civil Rights Cases, 1989

7613

2. Less Number of Cases, 1970

3. Equals Total Case Increase to be Explained

4. Less Increase in Volume of Cases Due to Economic or Demographic Factors

Of which, increase due to effects of:

2121

5. Growth in unemployment

Cases Line 3

$1416 \quad 19.5$

6. Demographic increase in "protected" work force

7. Replacement of older by younger cohorts

8. Less Increase in Volume of Cases Due to Legal or Policy

Changes:

Of which, increase due to effects of:

9. Cases brought by U.S. Government as plaintiff

10. Cases brought under ADEA

11. Cases challenging discrimination on basis of pregnancy, reverse discrinimation, or under $\S 1981$

12. Cases brought under Griggs v. Duke Power (disparate impact theories)

13. Cases due to 1972 changes in Title VII coverage 
unemployment rate is largely beyond the government's scope of influence. ${ }^{8}$ In brief, Table 2 suggests that the single most important factor explaining the growth in the employment discrimination caseload over the period from FY 1970-1989 is the increase in the unemployment rate. This factor explains roughly 20 percent of the growth in litigation. The increase in the protected work force generated by both the Age Discrimination in Employment Act (ADEA) ${ }^{9}$ and the 1972 Title VII amendments ${ }^{10}$ account for about another 20 percent of the growth in litigation between FY 1970 and 1989.11 Other doctrinal developments, ${ }^{12}$ and the direct role of the federal government, ${ }^{13}$ are noticeably less important factors. Moreover, even given the likelihood of double counting, which would inflate the "explained" portion of the increase, we are still left with a substantial unexplained residualroughly one-third of the caseload growth is unaccounted for by the factors set forth in Table 2.

\section{Growth attributable to "economic" or "social" factors.}

The rise in unemployment. We have already noted the effect of unemployment on the cyclical variation in the number of suits. ${ }^{14}$ But unemploy-

8. Of course, "exogenous" must be used with care since some of the endogenous factors will have second-order effects. For example, to the extent that labor force participation is a function of actual or perceived work place discrimination, changes in the law may influence the volume of litigation indirectly by encouraging labor force participation. We ignore such second-order effects here.

The methods used to disaggregate the sources of growth in case filings have two other shortcomings because the demographic/economic effects almost certainly involve substantial overlap with the legal/policy effects. First, growth attributable to two causal factors must be arbitrarily apportioned between them. For example, we demonstrate that the rise in unemployment rates accounts for roughly one-fifth of the increase in the employment discrimination caseload. We also argue that roughly $11 \%$ of the increased caseload is attributable to the Age Discrimination in Employment Act. However, the two sources of growth are clearly not independent. When the economy goes into a slump and firms retrench by laying-off older workers, some of them will sue under the ADEA. Should we attribute this litigation to the ADEA itself or to the exogenous economic conditions that motivated the suit? Clearly, both the law and the economic downturn are responsible for the increase in litigation. Our solution is to assume that the "pure" effects of changes in the law are measured by the increase in the non-economic caseload. Thus, before calculating the effects of the legal/policy factors, we subtracted the effects of the economic factors and then we applied growth estimates derived from other sources (such as the ABF Survey data) to the remaining cases. This left 5492 cases $(7613-2121=5492)$ as a base against which we could apply growth rates.

Second, it is important to recognize that a certain amount of double counting exists and to regard the estimates of the explained growth presented in Table 2 as upper bounds. For example, we note that EEOC-initiated suits contributed to the caseload growth as did new doctrinal theories of discrimination (such as the disparate impact theory). Since the EEOC presumably brings some of the disparate impact cases, there is some double counting in those categories. We should underscore that because the decomposition is done in a piecemeal fashion from disparate data sets, the resulting figures are best thought of as suggestive approximations of the complex reality.

9. Age Discrimination in Employment Act, Pub. L. No. 90-202, 81 Stat. 602 (1967) (codified as amended at 29 U.S.C. $\S \S 621-634(1988))$.

10. Equal Employment Opportunities Act, Pub. L. No. 92-261, § 4, 86 Stat. 103, 104 (1972) (codified at 42 U.S.C. $\$ 2000 \mathrm{e}-5(1988)$ ).

11. See notes 44-49 \& 58-62 infra and accompanying texts.

12. See notes $50-57$ infra and accompanying texts.

13. See text accompanying note 37 infra; notes 66-67 infra and accompanying text.

14. See notes 3-5 supra and accompanying text. Siegelman, supra note 3, provides a more extensive analysis. 
ment has also contributed to the long-run upward trend in the volume of cases. Between 1969 and 1989, there has been roughly a 2.31 percentage point increase in the unemployment rate. ${ }^{15}$ To calculate the effect of this long-term rise in unemployment on the number of employment discrimination cases filed, we first regressed quarterly unemployment rates on a constant, TIME, and TIME $^{2}$, using maximum likelihood estimation with corrections for first order autocorrelated errors. This yielded the following equations (t-statistics in parentheses) ${ }^{16}$
(a) $\mathrm{UNEM}_{-1}=3.44+0.180(\mathrm{TIME})-0.00187\left(\mathrm{TIME}^{2}\right)$
(b) $\mathrm{UNEM}_{-2}=3.37+0.179$ (TIME) $-0.0018\left(\right.$ TIME $\left.^{2}\right)$
(3.63) $(3.41)$
$(-2.94)$

Thus, over the eighty quarters between 1969 and 1989, the total increase in the one period lagged unemployment rate was

$$
(0.180 \times 79)-0.00187 \times\left(80^{2}-1\right)=2.25
$$

percentage points; the increase in the two-period lagged unemployment rate was 2.38 percentage points.

We then regressed the number of nongovernment employment discrimination cases filed (NUMBER) on TIME and TIME ${ }^{2}$ and on the detrended unemployment rates (DUNEMP ${ }_{-1}$ and DUNEMP -2 ) (the residuals from the two previous regressions). ${ }^{17}$ The estimated equation was

$$
\text { (c) } \begin{aligned}
\text { NuMBer } & =114.36+33.30(\text { TMM })-0.106\left(\text { TIME}^{2}\right) \\
& (1.10) \quad(5.34) \quad(-1.41) \\
& +100.79\left(\text { DUNEMP }_{-1}\right)+43.01\left(\text { DUNEMP }_{-2}\right)
\end{aligned}
$$

(Note that the standard errors on the unemployment variables have been corrected to reflect the fact that the independent variable is itself an estimated quantity.) The contribution of the increase in unemployment to the growth of cases is thus

$$
(2.25 \times 100.79)+(2.38 \times 43.01)=329.1
$$

15. Not only has the unemployment rate increased over this period, but the distribution of durations of unemployment spells has also shifted. See Kevin M. Murphy \& Robert H. Topel, The Evolution of Unemployment in the United States: 1968-1985, in THE NBER MACROECONOMICS ANNUAL 1987, at 25-26 (S. Fischer ed.) ("[B]etween survey years 1971-1973 and 1982-1985, unemployed weeks for the average individual increased by about 12 weeks per year ( 66 percent). Of this increase . . . 93 percent [is accounted for] by persons who were unemployed for more than 15 weeks.").

16. Unemployment rate data are from U.S. DEPARTMENT OF COMMERCE, supra note 4.

17. Again, maximum likelihood with AR1 error correction was used, $t$-statistics are in parentheses. To avoid double counting in line 9 of Table 2, we exclude all cases brought by the U.S. government as plaintiff. That is, NUMBER $=$ Number of cases filed in which U.S. government is not the plaintiff. Accordingly, NUMBER is less than CASES in Table 1. 
extra cases by the second quarter of 1989 , or, applying this same approach to the preceding three quarters, 1416 extra cases for the final year of our data.

"Demographic" growth in the protected work force. ${ }^{18}$. The population of workers eligible to sue under federal employment discrimination statutes has been rising throughout the period in question. Our Table 2 decomposition of the factors generating the growth in employment discrimination accounts for the effects of demographic/economic forces expanding the protected work force (line 6) separately from policy-induced expansions (line 13). Most of the growth in the eligible population since 1973 arises from demographic or economic factors-population growth as a whole and the increased participation of women in the labor force. ${ }^{19}$ Legislative decisions (the ADEA and changes in Title VII coverage) also expanded the population of workers protected by civil rights legislation, especially in the period between 1966 and 1973. The effect of these legislative actions are estimated in the following section.

As is apparent from Figure 3, the steady increase in both the female labor force and the total work force clearly accounts for most of the rise in the protected work force after 1973. The effects of the 1972 Title VII amendments $^{20}$ (which took effect in 1973) also appear. Overall, the protected population rose from 45.84 million in 1969 to 89.70 million in 1989, an increase of 95.7 percent (roughly 3.4 percent per year). ${ }^{21}$ However, 15.45 million (one-third) of this growth in population arises from the 1972 Amendments. ${ }^{22}$ Thus, the population increase attributable to demographic factors is 28.41 million, ${ }^{23}$ or 62 percent. This implies that demographic growth in the population of protected workers contributed about 544 suits to the volume of employment discrimination litigation. ${ }^{24}$

The cohort effect. Recent work by Peter Kuhn suggests a cohort effect in women's (and perhaps, by extension, other groups') experiences with discrimination. ${ }^{25}$ As older, less-educated cohorts of women leave the work force, younger cohorts with different expectations and higher levels of human capital replace them. Because "young, well educated women ... are

18. The "protected" work force as defined by the EEOC includes women, minorities, and white males over age 40 , and now comprises more than $70 \%$ of the total labor force. 1982 EEOC, supra note 3, at 16. This is a narrow definition of the "protected" work force. For example, young white males can, and occasionally have, sued for reverse discrimination under both Title VII and $\S 1981$, so the notion of eligibility is not a strict one. See, e.g., Jett v. Dallas Indep. School Dist., 109 S. Ct. 2702 (1989) (white high school football coach prevails in § 1981 employment discrimination case after being fired by a black principal).

19. Judicial interpretations, such as the extension of $\S 1981$ remedies to cases of employment discrimination and the recognition of reverse discrimination claims, also expanded definitions of protection. See text accompanying notes 50-57 infra.

20. See notes $59-60$ infra and accompanying text.

21. See Figure 3.

22. For the derivation of this estimate, see note 61 infra and accompanying text.

23. $89.70-45.84-15.45=28.41$.

24. That is, $1.62 \times 336=544$.

25. See Peter Kuhn, Sex Discrimination in Labor Markets: The Role of Statistical Evidence, 77 AM. ECON. REV. 567 (1987). 


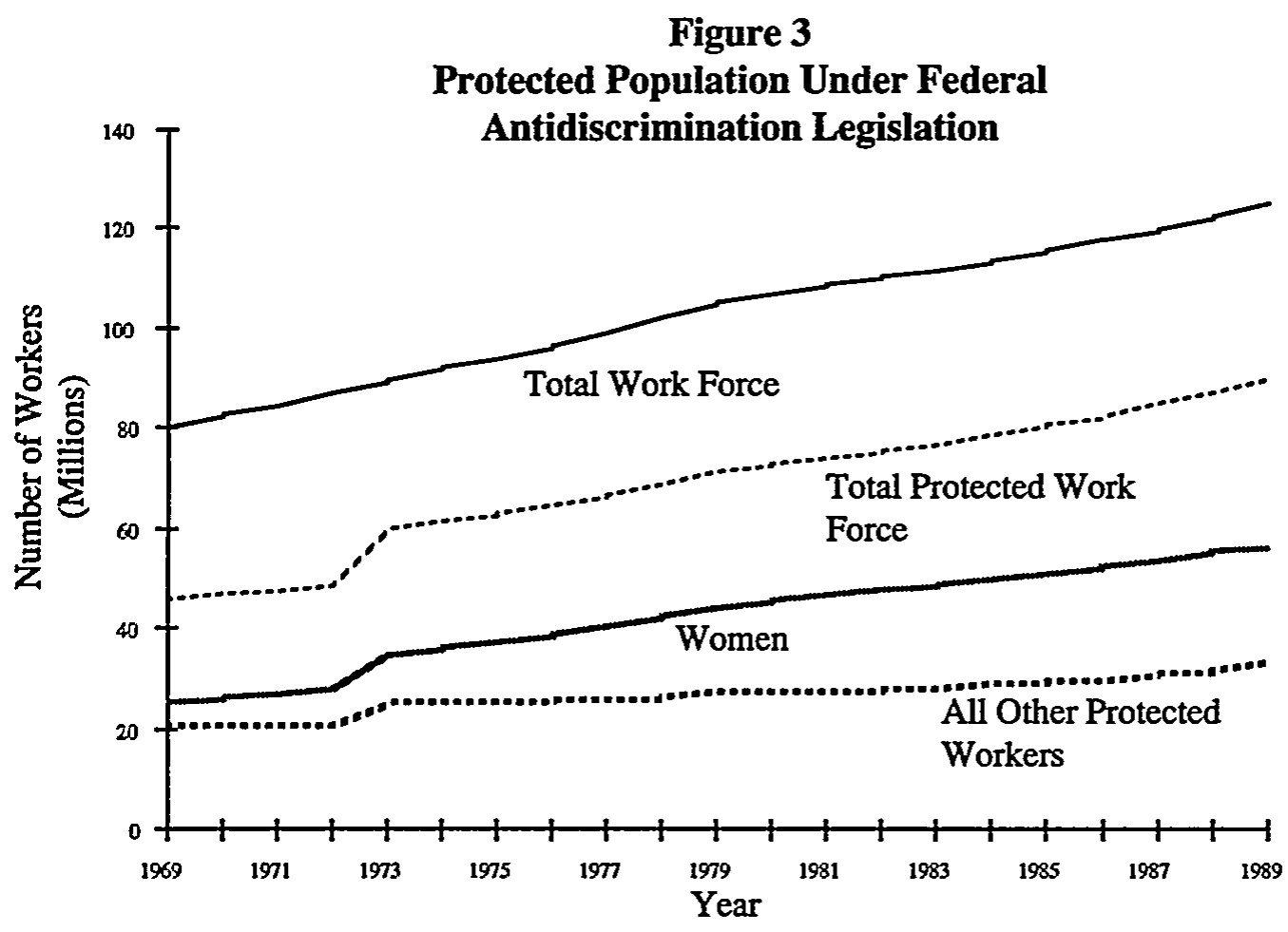

Sources: U.S. Department of LABor, BuREau of Labor Statistics, HandBook OF LABOR STATISTICS (1989); U.S. DEPARTMENT OF COMMERCE, BUREAU OF THE Census, Statistical Abstract of the U.S. (1989); and calculations described in text.

much more likely to report discrimination,"26 the number of sex discrimination suits should rise, even if the total number of women in the work force remained constant. In a 1977 study, Barbara Curran found a similar pattern among black and Hispanic workers. ${ }^{27}$

To raise a bona fide claim of employment discrimination, a worker must first perceive that discrimination has occurred. Clearly, the ability to detect violations of one's rights-and, once detected, to categorize such violations as legally actionable - depends not only on the grossness of the violation but also on one's education, legal sophistication, and general perceptions of one's rights. Younger women and minorities may experience less wage discrimination (measured as the difference between marginal product and actual wages) than their older counterparts. Yet their higher levels of education and greater expectations of equal treatment make them more able and will-

26. Id. at 568 .

27. Barbara A. Curran, The legal Needs of the Public: The final Report of a NAtional SURVEy 108 (1977). Among blacks and Hispanics, 25\% of respondents in the 18-34 age group stated that they had experienced discrimination in employment; less than $8 \%$ of those aged 55 years and over said they had experienced such discrimination. Since those in the over-55 age group had lived, on average, more than twice as long as those in the 18-34 age group, the pattern of responses strongly suggests that sensitivity to discrimination is higher for younger blacks and Hispanics. Curran did not find statistically significant differences across income levels. However, "[t]he mean education of those reporting job discrimination was $[1.1$ years] higher . . . than was that of those who reported never having confronted job discrimination ...." Id. 
ing to categorize their experiences as discriminatory. ${ }^{28}$

We calculate that the replacement of older by younger workers between 1969 and 1989 increased the volume of employment discrimination suits by about 161 suits. Between 1969 and 1989, the total work force grew from 81.75 million to 123.92 million-an increase of 42.17 million. ${ }^{29}$ The number of new entrants over this period totalled roughly 47.5 million, ${ }^{30}$ which requires that 5.33 million individuals left the labor market. Since the vast majority of those leaving the labor market are over age 40 or women, ${ }^{31}$ we assume that all of these 5.33 million were "protected" workers. If the "protected" work force grew by 43.86 million $^{32}$ between 1969 and 1989, and 5.33 million "protected" workers left the work force over this period, the number of "protected" entrants must have been 49.19 million.

There were 336 suits in FY 1970, and 45.84 million protected workers, or one suit for each 136,428 protected workers. Using Curran's findings that younger workers are roughly three times more likely to perceive themselves as victims of job discrimination than older workers, ${ }^{33}$ we assume that new entrants in 1970 would sue at three times the rate of their existing counterparts. ${ }^{34}$ Consequently, the estimated 5.33 million retirees would have been suing at a rate of $.5 / 136,428$ and the 49.19 million new entrants will be suing at a rate of $1.5 / 136,428$, yielding a net increase of

$$
(1.5 / 136,428 \times 49.19 \text { million })-(.5 / 136,428 \times 5.33 \text { million })=520
$$

suits over the period from 1969 to 1989.

This figure reflects the effect of a larger population of protected workers-because the entrants outnumber the retirees-as well as the higher propensity of younger workers to sue. Because the increase attributable to

28. A number of studies support the findings of Kuhn and Curran by suggesting that discrimination suits are disproportionately concentrated among the well-to-do and the well-educated. See, e.g., Richard E. Miller \& Austin Sarat, Grievances, Claims and Disputes: Assessing the Adversary Culture, 15 LAW \& Soc'Y REv. 525, 548, 553, 557 (1980-1981) (finding significant and large effects of income and education on: (1) grievance rates; (2) the probability of a grievance becoming a claim; and (3) the probability of a claim becoming a dispute); Trudy Mills, On The Use of Equal Employment Laws, 24 PAC. Soc. REv. 196 (1981) (white-collar and professional women are over-represented in a study of 98 district court cases alleging sex discrimination; however, no data are presented that allow one to assess this claim); Leonard Zeitz, Survey of Negro Attitudes Toward Law, 19 RUTGERS L. REV. 288, 310 (1965) (concluding from a survey of blacks in Newark that those who complained to the state Fair Employment Practices Commission were "markedly different [from the total black population] in socio-economic characteristics. They have much higher educational attainments and far greater incomes. ... [T] hey resemble the white middle class ... [more than] the majority of [blacks]."); Toward Equal Opportunity in Employment: The Role of State and Local Government, 14 BufFalo L. REv. iii (1964) (making claims similar to Zeitz on the basis of more impressionistic evidence).

29. See Figure 3.

30. Id.

31. Most male workers do not leave the labor force for an extended period until they retire, which usually occurs after age 60 . Robert J. Flanagan, LAWRENCE M. KaHN, Robert S. SMITH, \& RONALD A. EHRENBURG, ECONOMICS OF THE EMPLOYMENT RELATIONSHIP 123 (1989).

32. 89.70 million -45.84 million. See Figure 3.

33. See B. Curran, supra note 27.

34. If the average rate of suit in 1970 is $1 / 136,428$, then the new entrants will presumably sue at a rate of $1.5 / 136,428$ and the retirees at a rate of $.5 / 136,428$. 
population growth has already been included in line 6 of Table 2, we must exclude it here. Thus, the amount of growth attributable purely to the cohort effect is $(.5 / 136,428 \times 49.19$ million $)-(.5 / 136,428 \times 5.33$ million $)=161$ suits. ${ }^{35}$

\section{Growth attributable to "legal" or "policy" changes.}

In the previous section we discussed some social or economic forces that contributed to the growth of the employment discrimination caseload. This section focuses on the caseload growth induced by government action-administrative, legislative, and judicial.

U.S. Government cases. We distinguish cases brought by the U.S. Government as plaintiff (most of which the Equal Employment Opportunity Commission (EEOC) files) from those brought by private citizens, since different factors usually motivate the two kinds of litigation. ${ }^{36}$

The increase in government-plaintiff litigation was derived in a straightforward fashion by simply taking the difference between the volume of government-plaintiff suits in FY 1970 (140) and FY 1989 (523)-yielding an increase of 383 suits. This figure represents only 5.3 percent of the 7277 additional cases in 1989, weakening any claim that the EEOC's expanded enforcement powers are responsible for a large proportion of the increase in employment discrimination cases filed. ${ }^{37}$

Innovations in selected legal doctrines. We next seek to derive estimates for the increases in cases filed due to: (1) the enactment of the ADEA and the Congressional prohibition of differential treatment on the basis of pregnancy; ${ }^{38}$ and (2) judicial decisions expanding the reach of Section $1981,{ }^{39}$ permitting reverse discrimination cases, and creating the disparate impact standard. 40 The following method was used to estimate lines 10 through 12 of Table 2: For each of the legal innovations, we assumed that no cases were brought under that theory prior to FY 1970, since the vast bulk of the cases

35. If the 49.19 million new entrants had sued at exactly the FY 1970 average rate of $1 / 136,428$, then these entrants would have generated

$$
1 / 136,428 \times 49.19 \text { million }=359
$$

more suits. The growth in cases purely due to the differing propensities to sue of the entering and existing cohorts is then

$$
520-359=161 \text {. }
$$

36. For example, we have already discussed how a robust economy will decrease the likelihood that a rejected worker who believes she has been the victim of employment discrimination will sue. Presumably, such factors would not influence government decisions to initiate litigation against an alleged discriminator.

37. See also notes 66-67 infra and accompanying text.

38. Initially, the Supreme Court held that pregnancy classifications were not necessarily improper sex classifications. General Electric v. Gilbert, 429 U.S. 125 (1976). This view was reversed by Congress two years later. Act of Oct. 31, 1978, Pub. L. No. 95-555, § 1, 92 Stat. 2076, 2076 (codified at 42 U.S.C. $\$ 2000 \mathrm{e}(\mathrm{k})$ (1988)).

39. The Supreme Court held that $\S 1981$ provides a private monetary remedy for racial discrimination in the making and enforcement of private contracts in Runyon v. McCrary, 427 U.S. 160 (1976).

40. Griggs v. Duke Power Co., 401 U.S. 424 (1971). 
generated by all the legal innovations came during the 1970 s. $^{41}$ Using data from the American Bar Foundation's (ABF) Survey of Employment Civil Rights Litigation, ${ }^{42}$ we calculated the proportion of all cases at the end of our sample period that stated a claim based on the legal innovation. ${ }^{43}$ Applying this share to the total volume of cases filed in 1989 produces the estimate of the effect of the legal change. Since by assumption no such claims were brought until 1970, the increase in litigation attributable to the legal innovation is the entire estimated volume of suits.

Consider first the Age Discrimination in Employment Act (ADEA). ${ }^{44}$ The Act took effect in $1968,{ }^{45}$ and, by the end of the ABF sample period, 15.1 percent of the Employment Civil Rights cases were based on age discrimination. ${ }^{46}$ Thus, we estimate that the ADEA increased litigation by 1150 additional cases filed in 1989.47 This estimate needs to be modified to correct for the double-counting problem. ${ }^{48}$ To do so, we subtract from the 1150 cases an amount equal to the share of age discrimination cases due to "Economic or Demographic Factors" (line 4, Table 2). This leaves

$$
0.151 \times(7613-2121)=829
$$

additional cases due exclusively to the passage of the ADEA. ${ }^{49}$

A number of other important innovations in the law of employment discrimination also contributed to the caseload growth over the last two decades. In 1975 and 1976, the Supreme Court expanded Section 1981's prohibition of discrimination against racial minorities in the "making and enforcement of contracts" to provide damages to those who proved employ-

41. This assumption is not absolutely correct. For example, the ADEA took effect in 1968. At least some cases would have been brought under its provisions prior to July 1969 (the beginning of FY 1970). Moreover, even though Griggs was not decided by the Supreme Court until 1971, a smattering of disparate impact cases had been filed in federal district courts prior to this date. Our assumption that changes in legal doctrine were not felt until after FY 1970 is obviously a conservative one that generates an upper-bound estimate of their effects.

42. ABF Survey, supra note 3.

43. To allow for a statistically reliable volume of cases, we used the last $21 / 4$ years for which we had data (1/1/85 through $3 / 31 / 87)$ as our sampling period.

44. 29 U.S.C. $\$ \S 621-634$ (1988). (1967).

45. See Age Discrimination in Employment Act, Pub. L. No. 90-202, § 15, 81 Stat. 602, 607

46. We define an age discrimination case as one that states a claim based on the ADEA and does not also state a claim based on race, sex, or some other protected category. The decision to exclude multiple-basis suits was based on the assumption that such cases would have been brought even if the age discrimination claim were not available. Given the superior remedies that are potentially available under the ADEA and the plaintiff's right to a jury trial (not available under Title VII), this assumption may result in an underestimation of the effects of the ADEA. If one includes all cases that raise an ADEA claim, whether or not this was the only basis of suit, the share of such claims (in the last $2 \frac{1}{2}$ years of our sample) rises from $15.1 \%$ to $19.8 \%$.

47. $0.151 \times 7613=1150$.

48. See note 8 supra.

49. We should underscore once again the arbitrariness of our correction for double counting. If an economic factor such as a higher unemployment rate combines with the existence of a new law such as the ADEA to generate a number of age discrimination suits, there is no single correct method to decompose the individual contribution of either factor. Our decomposition tends to increase the size of the contribution of economic and social factors. 
ment discrimination. ${ }^{50}$ Also in 1976 , the Supreme Court first recognized a cause of action for reverse discrimination, ${ }^{51}$ and in 1978, Congress authorized a cause of action for women who were treated discriminatorily due to pregnancy. ${ }^{52}$ Using the same technique described to estimate the effects of the ADEA, we found that together, these new doctrines generated an increase in litigation of 703 suits. ${ }^{53}$

Table 3

Volume of Employment Civil Rights Cases

Raising a \$ 1981 Claim

$1972-1976 \quad 1977-1981 \quad 1982-1987$

Number of Cases that:

1. Raised a § 1981 Claim $^{\mathrm{a}}$

2. Raised only a § 1981 Claim

3. Line 1 as a Percent of All
112

1
151

9

34.4
147

9

27.0

a. Either alone or in conjunction with a claim under another statute.

Source: American Bar Foundation Employment Discrimination Litigation Survey, Computer File (1990) (on file with the authors). Figures exclude 23 of the 1247 sample cases for which filing data was missing.

In evaluating the contribution of Section 1981, we assume that any case that raised a Title VII claim in addition to the Section 1981 count would have been brought even if the Section 1981 remedy were unavailable. Table 3 shows that the number of employment discrimination cases raising only a Section 1981 claim is quite small. A less restrictive assumption would enhance the significance of the contribution of Section 1981 to the employment discrimination caseload growth. Somewhat surprisingly, Table 3 demonstrates that the percentage of cases that raised a Section 1981 claim (either

50. Runyon v. McCrary, 427 U.S. 160, 172 (1976) (quoting Johnson v. Railway Express Agency, 421 U.S. 454, 459-460 (1975)). The Court recently held that $\S 1981$ protection extends only to contract formation (hiring) and not to on-the-job discrimination. Patterson v. McLean Credit Union, 491 U.S. 164 (1989). Whether $\S 1981$ covers firing remains uncertain. The implications of Patterson are not important for the present discussion because it was decided too recently to have affected our case data.

51. McDonald v. Santa Fe Trails, 427 U.S. 273 (1976).

52. See note 38 supra.

53. More precisely, pregnancy cases constituted $2.8 \%$ of the cases in the ABF Survey between $1 / 1 / 85$ and $3 / 21 / 87$, reverse discrimination cases comprised $5.6 \%$, and $\S 1981$ cases (without any reference to Title VIn) amounted to $4.4 \%$, for a total of $12.8 \%$. See ABF Survey, supra note 3 . This implies that the estimated effect of these laws is $0.128 \times(7613-2121)=703$ additional cases. Note that the subtraction of the 2121 economically and demographically motivated cases (Table 2, line 4) is our correction for double counting. 
alone or in conjunction with a Title VII claim) diminished after the 1975 and 1976 expansions by the Court.

The disparate impact definition of discrimination, first recognized by the Supreme Court in the landmark case of Griggs v. Duke Power Co. ${ }^{54}$ is generally considered to be the most important innovation in the legal doctrine defining employment discrimination. ${ }^{55}$ Indeed, one commentator has recently suggested that "[Title VII originally] banned what civil-rights lawyers call 'disparate treatment'; by now, most litigation is instead about 'disparate impact.".56 Yet whatever its effects on labor market performance by firms and workers, it appears to have had only an extremely modest influence on the volume of litigation. We estimate that the disparate impact doctrine generated only 101 additional cases in 1989.57

The 1972 amendments to Title VII. Title VII was amended in 1972.58 Besides expanding the EEOC's enforcement powers, ${ }^{59}$ the major impact of the amendment was to increase the population covered by Title VII to include those working in firms with 15 to 25 employees, employees of state and local governments, and employees of educational institutions, all of whom had formerly been outside of Title VII's protection. ${ }^{60}$ We estimate that these changes created an additional 683 cases in 1989.

We derived this result in two stages. First, we estimated that the 1972 amendment's broadening language increased the covered worker population by about 11.12 million workers. ${ }^{61}$ Assuming that this worker population

54. 401 U.S. 424 (1971).

55. See, e.g., Paul Cox, Employment Discrimination ch. 7 (1987); Michael Evan Gold, Griggs' Folly: An Essay on the Theory, Problems and Origin of the Adverse Impact Definition of Employment Discrimination and a Recommendation for Reform, 7 INDUS. REL. L.J. 429 (1985). The recent Supreme Court decision in Wards Cove Packing Co. v. Antonio, 490 U.S. 642 (1989), eroded the disparate impact doctrine promulgated in Griggs.

56. L.G. Crovitz, Defenders of the Civil-Rights Bill Doth Protest Too Much, Wall St. J., Feb. 20, 1991, at A15, col. 3 (emphasis added).

57. Again, the proportion of disparate impact cases in the ABF Survey between $1 / 1 / 85$ and $3 / 31 / 87$ was $1.84 \%$. ABF Survey, supra note 3 . Once again, we assume that a case that raises both a disparate impact and a disparate treatment count would have been brought even if the Supreme Court had never recognized the disparate impact theory. In our entire sample, only 19 of the 1029 cases in which we could ascertain the nature of the complaint raised both disparate impact and disparate treatment claims. We calculate that the increase in disparate impact cases from 1969 to 1989 was $0.0184 \times(7613-2121)=101$. Note that this figure does not demonstrate whether or not Griggs had an infuence on employer behavior, which could have changed substantially in order to avoid future lawsuits. The calculation suggests only that Griggs is not explicitly responsible for much of the observed growth in litigation.

58. Equal Employment Opportunities Act, Pub. L. No. 92-261, § 4, 86 Stat. 103, 104 (1972) (codified at 42 U.S.C. $\$ 2000 \mathrm{e}-5(1988)$ ).

59. See 42 U.S.C. $\S 2000 \mathrm{e}-5(\mathrm{a})$ (1988).

60. 42 U.S.C. $\S 2000$ e(b) (1988).

61. There were 3.945 million workers in firms with 10-19 employees, and 5.373 million workers in firms with 20-49 employees. Telephone interview with official from Dept. on Manufacturing, U.S. Bureau of Census (1990) (notes on file with the Stanford Law Review). Assuming uniform distribution within these categories, there were $[(19-15+1) /(19-10+1)] \times 3.945=1.972$ million workers in firms with $15-19$ workers and $[(25-20+1) /(49-20+1)] \times 5.373=1.075$ million workers in firms with 20-25 workers. Thus, the work force in firms with 15-25 employees was 3.047 million. Not all of these workers were "protected," however. We estimate that women and minority men constituted $65.6 \%$ of the total labor force of 89.429 million in 1973. Assuming 
grew at the same rate as the protected labor force as a whole over the period of our study, there would be 39 percent more protected workers in the categories added by the 1972 reforms by 1989 , for a total of 15.45 million such workers.

Second, we estimated how many employment discrimination suits these additional 15.45 million workers were likely to bring. Since these "added" protected workers constitute 12.46 percent of the total 1989 work force of 124 million, ${ }^{62}$ the simplest estimate would attribute to them the same share of the total volume of litigation, or 946 suits in 1989. Again, we must correct for double-counting, however, yielding

$$
0.1246 \times(7613-2121)=684 .
$$

Since these workers brought no suits in 1970 (by assumption), the increase in litigation attributable to the 1972 expansion is thus all 684 suits.

\section{Findings}

Despite the broad brush with which Table 2 is painted, it does reveal some important facts about the growth in employment discrimination. Perhaps the most important conclusion we draw from our analysis of the growth in the volume of employment discrimination litigation is that a healthy economy is a strong ally of those whom the antidiscrimination laws are designed to protect. When unemployment rates are low and labor markets are tight, workers probably encounter less discrimination and are certainly better positioned to seek remedies outside the litigation process for any discrimination they do encounter. ${ }^{63}$ The link between macroeconomic performance and the number of employment discrimination filings is therefore a strong one. For example, the results in Table 1 imply that if the unemployment rate had remained at its 1969 low of 3.9 percent, 33,600 (32.5 percent) fewer employment discrimination cases would have been filed in federal courts and 537,600 fewer charges would have been filed with the EEOC between 1969 and 1989.64 The increase in the unemployment rate

that they comprised a similar proportion of the work force in small firms, only $0.656 \times 3.047=$ 1.999 million protected workers were added. However, the Census sample (45.81 million) did not cover the entire work force; thus the estimate needs to be blown-up by $(89.429 / 45.81)=195.2 \%$. This suggests that lowering the minimum firm size added about 3.9 million workers to the protected category.

There were approximately 11 million state and local government employees in 1972 (including educational employees). Of these, we assume that $65.6 \%$ were women or minority men, so 7.21 million protected workers were added by the expanded coverage of Title VII. In total, the amendments thus added about 11.12 million protected workers to those already covered by Title VII.

62. U.S. Department OF CoMmerce, SuRvey OF CuRRENT Business 59 (Jan. 1991). We would have obtained a higher estimate of the impact of the 1972 amendments if we had assumed that all suits came from the protected work force and thereby calculated the percentage these $\mathbf{1 5 . 4 5}$ million workers were of the protected rather than total work force.

63. For a fuller explanation of the link between unemployment rates and the volume of litigation, see Siegelman, supra note 3, at chs. 2, 5 .

64. We used the regression results of Table 1 to estimate that 33,600 fewer employment discrimination cases would have been filed had the unemployment rate remained constant at $3.9 \%$. We can then use the fact that the average ratio of federal court cases to EEOC charges, weighted by the number of cases, is 0.0625 to predict that the total number of EEOC charges would fall by 537,600 . 
has had a major effect on the volume of litigation, by itself explaining 19.5 percent of the growth in cases since 1969. Other exogenous economic factors seem less significant in explaining the rising caseload.

Second, the ADEA and the 1972 Title VII Amendments have clearly had an important influence on the volume of litigation. Without the expansion of protection offered by these laws, roughly 20 percent less litigation would have occurred in 1989 . In contrast, relatively little growth in litigation arises from changes in judicial doctrines. This finding contradicts those who have argued that changes in legal doctrine can explain almost all growth in employment litigation. ${ }^{65}$

Finally, we conclude from our analysis that the EEOC has played an essentially passive role in the growth of employment discrimination suits. First, it has brought relatively few cases. ${ }^{66}$ Second, it seems not to have been responsible for the growth in private litigation. As illustrated in Figure 4, the ratio of EEOC cases to federal district court cases has remained fairly constant during the period from 1975 to 1986.67 If roughly the same proportion of EEOC charges turns into federal court complaints each year, then the EEOC's processing of such charges cannot be responsible for the growth in litigation. Rather, it makes more sense to think of the Commission as a screening device that has consistently filtered out about 95 percent of the charges filed with it. This view is substantiated by the fact that the composition of charges heard by the EEOC is virtually identical to the makeup of cases filed in federal court: Both sets of cases contain the same proportion of hiring and firing disputes, race versus sex discrimination claims, and so on. ${ }^{68}$

Even given the potential double-counting problems discussed earlier, roughly one-third of the growth in litigation is not attributable to any of the factors analyzed in Table 2. This implies considerable work is still needed to explain the growth in the caseload, a topic to which we now turn.

\section{EXPLAINING THE RESIDUAL}

This section begins by confronting several popular explanations for the

65. See, e.g., Ali-ABA Committee on Continuing Professional Education, EmployMENT Discrimination and Civil Rights Actions in Federal and State Courts (1989) ("The tremendous growth in such cases has been due primarily to landmark decisions by the U.S. and state supreme courts, federal and state appellate and trial tribunals, and recently enacted statutes."); Equal Employment Advisory Commission, Reply to the Preliminary RecomMENDATIONS OF THE FEDERAL COURT STUDY COMMISSION 3 (1990) ("increased litigation has been brought about by two primary factors-additional statutory private rights of action created by Congress and the courts plus the 1972 Title VII amendments that gave litigation authority to the EEOC").

66. The EEOC was granted the right to bring suit in 1972. Between then and 1989, it brought only 4356 cases, less than $4 \%$ of all employment discrimination litigation between 1969 and 1989.

67. The average annual ratio of federal court cases to EEOC complaints during the period from FY 1970-1987 was 5.7\%, with a standard deviation of $1.8 \%$. If one weights the annual ratio by the number of employment discrimination cases then the average is $6.25 \%$, with a standard deviation of $1.63 \%$. The reason for the significant rise in the ratio in the first half of the 1970 s is the growing length of time it took the EEOC to process a charge. The ratio of cases filed to charges disposed of shows no change over this period. See Siegelman, supra note 3, for further details.

68. See text accompanying note 102 infra. 
growth in employment discrimination litigation: first, an actual increase in discrimination; second, promotion of litigation by lawyers; and third, changes in the propensity to sue. We conclude that none of these explanations is supported by the evidence. We then offer two explanations that are consistent with increasing litigation in an era of declining discrimination. The movement of minorities and women into better and more integrated jobs may explain some of the residual growth not accounted for in the analysis underlying Table 2 . We demonstrate a positive relationship between a worker's wage and her propensity to sue for employment discrimination. This relationship arises because the benefits of a successful suit are proportional to the worker's wage, while the costs of bringing suit contain an important fixed element. In addition, we argue that integrated work forces are more likely to produce litigation because minorities or women who work by themselves have no benchmarks (whites or males) against whom they can measure their treatment and determine whether or not it is discriminatory.

Although neither of these effects can be tested or measured directly, we do produce evidence that they are consonant with the observed progress of minorities and women into better and more integrated jobs.

\section{A. Dismissing Some Traditional Explanations for the Growing Volume of Litigation}

1. Growth in discrimination.

Although the rising volume of employment discrimination litigation could conceivably be explained by increasing levels of race and sex discrimination, the social science and survey literature suggests that, by most measures of attitudes towards women and minorities in the work place, prejudice has been declining for decades. Two 1985 surveys on racial attitudes concluded that racist beliefs have been steadily declining over the past forty years. ${ }^{69}$ A number of surveys have also suggested that inhospitable attitudes toward women in the work place have softened over the last twenty years. ${ }^{70}$ While these studies document changes in articulated beliefs and external conduct, they cannot, of course, answer the important question whether this trend represents true behavioral change or merely increased hypocrisy.

Additional evidence from fair housing audits-in which teams of black and white "testers" attempt to buy houses in certain neighborhoods-indicates that housing discrimination against blacks has followed a pattern of decline similar to that reflected in the attitudinal surveys. ${ }^{71}$ Finally, there is

69. Paul Burstein, Discrimination, Jobs, and Polmtics (1985); Howard Schuman, Charlotte Steeh \& Lawrence Bobo, Racial. Attitudes in AMerica: Trends and INTERPRETATIONS (1985).

70. See John J. Donohue, Prohibiting Sex Discrimination in the Workplace: An Economic Perspective, 56 U. CHI. L. REv. 1337, 1338-41 (1989); Charlotte Decker Sutton \& Kris K. Moore, Executive Women-20 Years Later, 1985 HARV. Bus. REV. 42, 48 (in 1965, 27\% of male and 75\% of female business executives said they would feel comfortable working for a woman; in 1985 the percentage had risen to $47 \%$ of males and $82 \%$ of females).

71. Richard H. Sander, Individual Rights and Demographic Realities: The Problem of Fair 


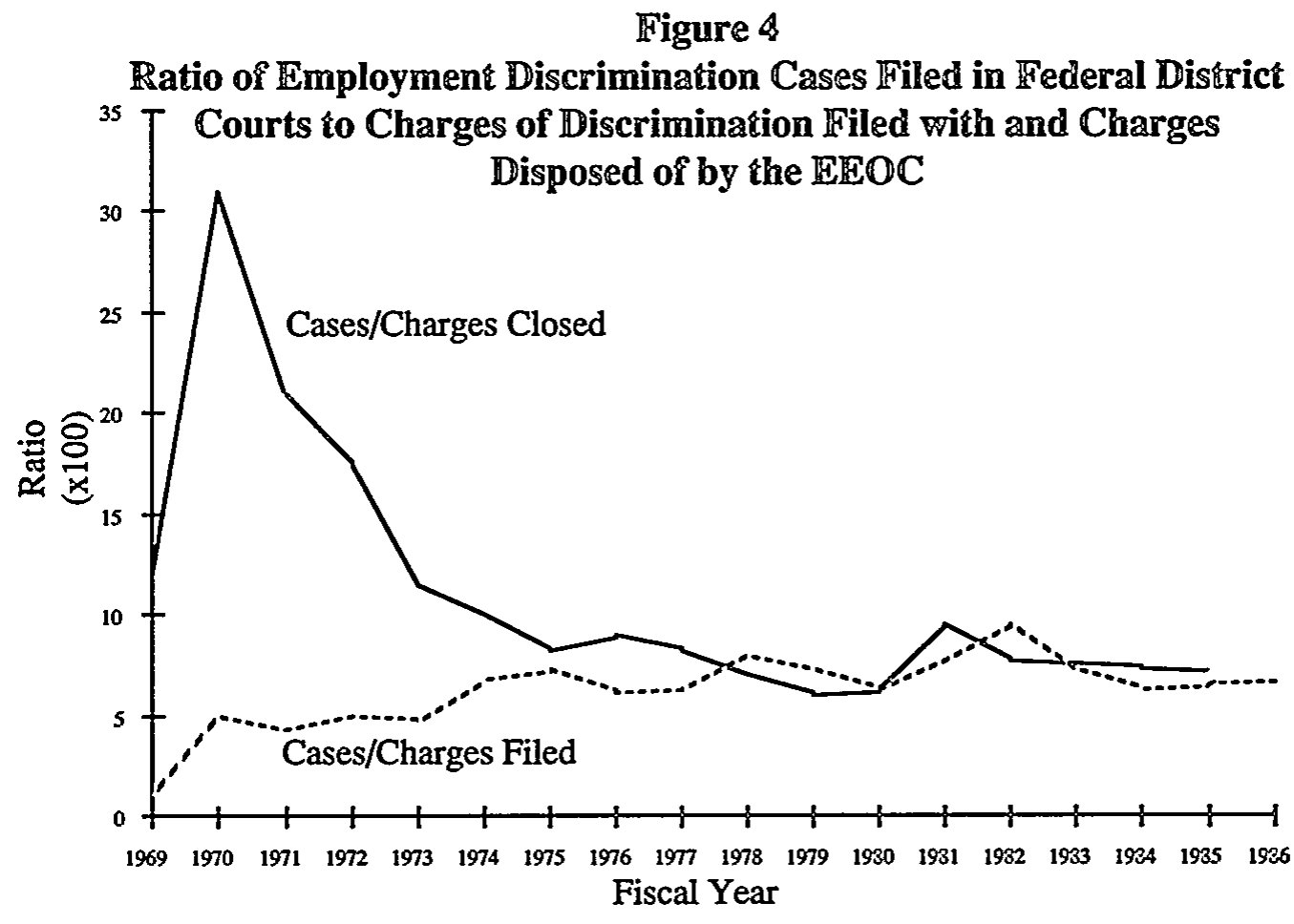

Sources: Administrative Office of the U.S. Courts, Computer File (1989) (on file with the authors); 1966-1985 EEOC ANN. REP.

indirect evidence that the amount of discrimination in labor markets-as measured by earnings regression equations and the trends in the black-white and male-female earnings ratios-has decreased since 1970, particularly for blacks in the South. ${ }^{72}$ In sum, while the evidence is scattered and of varying

Housing, 82 Nw. U.L. REv. 874 (1988). Of course, whether this results from better enforcement of fair housing laws or from a decline in discriminatory attitudes is unclear. For another interesting illustration of apparent racial and gender discrimination, this in the sales of automobiles, see Ian Ayres, Fair Driving: Gender and Race Discrimination in Retail Car Negotiations, 104 HARV. L. REv. 817 (1991).

72. The numerous studies of black/white or female/male wage ratios provide some evidence about discrimination, although most of these studies use cross-sectional rather than time-series data. Glen G. Cain, The Economic Analysis of Labor Market Discrimination: A Survey, in 1 HANDBook OF LABOR ECONOMICs 693, 750-51, 760 (O. Ashenfelter \& R. Layard eds. 1986) (Tables 13.6 \& 13.7); see John J. Donohue \& James J. Heckman, Continuous Versus Episodic Change: The Impact of Civil Rights Policy on the Economic Status of Blacks, - J. ECON. LITERATURE - (1991) (forthcoming) (using time-series data to show that the unexplained earnings deficit of black males fell dramatically from 1965 to 1975 , with almost all of the progress coming in the South, but then grew modestly in the 1980s).

One potential shortcoming of these studies is that they focus exclusively on discrimination in wages. Apart from the recent work of James J. Heckman \& Brook S. Payner, Determining the Impact of Federal Antidiscrimination Policy on the Economic Status of Blacks: A Study of South Carolina, 79 AM. ECON. REv. 138 (1989), there has been little discussion of discrimination in hiring or firing, which are far more common complaints than wage discrimination. The difference between discrimination in hiring and firing and discrimination in pay could be significant. Conceivably, studies looking at black-white wage differentials might not observe any disparity if labor market discrimination led to the firing of or failure to hire workers. For discussions of the studies focusing on the effect on black-white wage ratios of black withdrawals from the labor market, see John J. Donohue, Further Thoughts on Employment Discrimination Legislation: A Reply to Judge Posner, 136 U. PA. L. REv. 523, 534-36 (1987); Donohue \& Heckman, supra. 
quality, it does suggest that discrimination has almost certainly not increased over the period from 1969-1989.

\section{Litigation promoted by lawyers.}

Another popular explanation for the increase in all federal civil litigation is that the increasing supply of lawyers spawns more litigation. But the percentage growth in the number of attorneys is far smaller than the percentage growth in the employment discrimination caseload. ${ }^{73}$ Therefore, if changes in the legal profession have contributed to the caseload growth it must be due to increased efficiency of law firms in processing complaints. Lawyer advertising may alert potential litigants to the possibility of lawsuits as well as reduce their search costs in finding representation. Legal clinics and prepaid legal services also may have increased the probability of suing about an unfavorable experience in the labor market. On the other hand, the increase in the number of lawyers and clinics handling employment discrimination could simply represent a response to an independent increase in litigant demand. ${ }^{74}$

\section{Changes in propensity to sue.}

One readily accepted explanation for the increase in litigation is that workers are simply more willing to sue today than in the past. The literature on the so-called litigation explosion suggests that Americans have generally become more litigious over the past twenty years, and one might imagine that this phenomenon is at work in the area of employment discrimination. ${ }^{75}$ In our view, this argument has several flaws.

First, it is virtually tautological. Propensity to sue is the result of various conscious and unconscious calculations made by potential plaintiffs. A satisfactory explanation for the growth in litigation must explain why the propensity to sue has increased.

Second, the argument fails to consider the difference in magnitude be-

73. While the population of lawyers grew $176 \%$ between 1970 and 1988 (from 274,000 to 757,000), Richard H. Sander \& E. Douglass Williams, Why Are There So Many Lawyers? Perspectives on a Turbulent Market, 14 L. \& Soc. INQUIRY 431 (1989) (Table 1), the number of civil cases commenced in federal district court rose $174 \%$ (from 87,300 to 239,600) and the number of these cases requiring court action shot up $228 \%$ (from 48,400 to 158,600 ), U.S. DEPARTMENT OF LABOR, Bureau of the Census, Statistical Abstract of the United States 1990, at 183 (Table 313). Meanwhile the employment discrimination caseload exploded 2,337\%, Admin. Off. File, supra note 2.

One might want to look at the growth in the number of lawyers most likely to handle employment discrimination litigation instead of the growth in the number of lawyers overall. Membership in the American Bar Association's Section on Labor and Employment Law is probably the best available measure of how many such lawyers there are. Membership rose from 3908 in May 1970 to 14,250 in May 1989, a 265\% increase. American Bar Foundation, Section Membership Report (Feb. 1990) (unpublished worksheet) (on file with the Stanford Law Review).

74. Judge Posner has written that "the increase in the supply of lawyers appears to have lagged behind rather than led the litigation explosion." RICHARD POSNER, THE FEDERAL COURTS: CRISIS AND REFORM 80 (1985).

75. For doubts about the existence of the litigation explosion, see Marc Galanter, The Day After the Litigation Explosion, 46 MD. L. REv. 3 (1986). 
tween the growth in employment discrimination litigation and that of other federal civil suits. Since the size of the growth in the employment discrimination caseload is vastly greater, it would appear to represent a qualitatively different phenomenon.

Despite these reservations, the argument that there has been an increase in propensity to sue by potential employment discrimination plaintiffs merits serious consideration. A recent survey conducted for the National Law Journal, for instance, found an apparent increase in the likelihood that an individual will sue if he or she experiences employment discrimination. ${ }^{76}$ We evaluate some of the available data to determine whether such an increase constitutes a plausible explanation for the observed increase in litigation.

The Curran report on the legal needs of the American public, based on interviews conducted in March 1974, showed that while perceived instances of job discrimination were not uncommon, the number of individuals perceiving the problem who then consulted a lawyer was trivial compared with other types of common legal problems. ${ }^{77}$ Figure 5, which is reprinted from the Curran report, demonstrates that of twenty-nine commonly encountered legal problems, the one least likely to lead to consultation with an attorney was job discrimination: Only 1 percent of those experiencing this problem consulted a lawyer upon the most recent occurrence. ${ }^{78}$ People overlook many perceived instances of discrimination when they retain their jobs, because the costs of suing a present employer can be high. Nonetheless, the Curran report shows that all growth in the federal employment discrimination caseload since March 1974 could be explained if the willingness to pursue legal remedies for perceived employment discrimination had risen to 2.33 percent, one-third the level of the next lowest item on the listproblems with municipal services ( 7 percent). ${ }^{79}$

76. In response to the question "Would you be more willing to take legal action today to fight what you perceived as discrimination than you would have been five years ago?" $62 \%$ of all respondents answered affirmatively. Randall Samborn, Many Americans Find Bias at Work, Nat'l L.J., July 16, 1990, at 1.

77. B. CURRAN, supra note 27 , at 146.

78. Id. at 136. Respondents who had encountered one of these 29 legal problems were also asked if they had taken any action in response to the most recent occurrence. Again, the lowest percentage-here $30 \%$ - was reported for those experiencing job discrimination. Id. at 137. One should evaluate the results of the Curran study in light of the evidence presented in Figure 1. Late 1973 and early 1974 were below trend in the number of employment discrimination cases filedlargely because of the healthy economy. The effect a robust economy will have on the likelihood of pursuing legal action depends on the nature of the complaint: A discriminatory firing or refusal to hire is less likely to generate a complaint during a boom than during a downturn, when the market may provide insufficient remedies; on the other hand, workers who perceive on-the-job discrimination might be more likely to take some action during a boom, which reduces the possibility of and the harm attendant to losing their jobs. Figure 1 suggests that the first effect dominates; this is not surprising, given that relatively few people sue their current employers. Our evidence suggests that fewer than 15 percent of all suits are brought against plaintiff' current employers, and this number would fall by one-third if government employees were excluded. ABF Survey, supra note 3; see also text accompanying note 145 infra.

79. Specifically, the number of cases filed in the year following the Curran interviews in March 
Figure 5

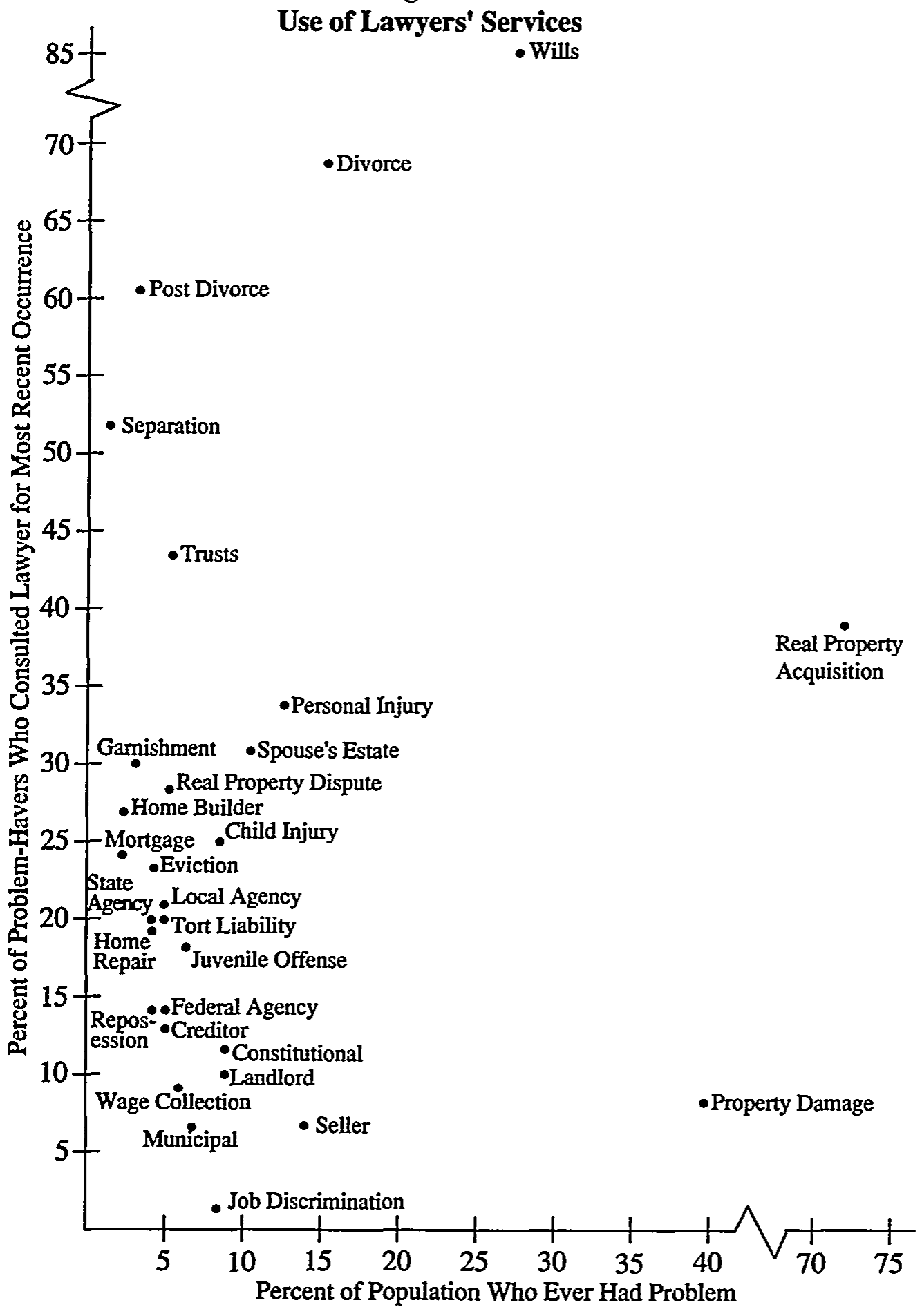

Source: Reproduced from Barbara A. CuRran, The Legal Needs of the Public: The Final Report of A National SurVey 135 (1977). 


\section{B. Two Explanations for the Residual Increases in Litigation}

\section{The "better jobs" effect.}

The propensity of a rejected worker ${ }^{80}$ to sue will typically be a positive function of the wage in the job from which she is rejected. To see why, take the case of a fired employee who is considering filing suit under Title VII. If she wins, damages under Title VII are limited to backpay for the time she was unemployed. ${ }^{81}$ Thus, we can approximate the award to a prevailing plaintiff by the product of her wage in her former job and the duration of her unemployment. ${ }^{82}$ The costs of bringing suit, by contrast, are generally fixed. ${ }^{83}$ Now define

$$
\begin{aligned}
& w=\text { weekly wage } \\
& D=\text { duration of unemployment } \\
& p=\text { probability of plaintiff victory if there is a suit } \\
& C_{p}=\text { plaintiff's cost of bringing the suit. }{ }^{84}
\end{aligned}
$$

1974 was 3,267 . The filings rose by $133 \%$ to 7,613 by FY 1989 . An increase in the propensity to sue of $133 \%$ would lead to suit in $2.33 \%$ of instances of perceived discrimination.

A January 1980 survey of 1000 households from five judicial districts around the country found that only $3.9 \%$ of those involved in a dispute over discrimination in housing, employment, or education actually brought a lawsuit. Again, the probability of bringing a suit was far lower for discrimination than for any other type of perceived injury. Miller \& Sarat, supra note 28. While this survey evidence may suggest a large increase in the litigation rate of those perceiving employment discrimination, the aggregation of housing and education discrimination cases with employment discrimination cases makes comparisons with the Curran report difficult.

80. By "rejected" we mean a worker who is fired, laid-off, not promoted, or not hired.

81. "[T]itle VII provides only equitable remedies; damages other than backpay are not recoverable." P. Cox, supra note 55, at 5-17; see 42 U.S.C. $\$ 2000 \mathrm{e}-5(\mathrm{~g})$ (1988). Reinstatement and promotion are also available as remedies, but our data suggest that they are rarely invoked. ABF Survey, supra note 3.

Alternative causes of action offer more generous damages, and their availability weakens our model somewhat. The Age Discrimination in Employment Act, for example, offers double recovery upon proof of willful violation of the statute. P. Cox, supra note 55, at 23-14; see, e.g., Fortino v. Quasar Co., 1990 US Dist. LexIS 16717 (N.D. Ill. 1990). Suits under $\$ 1981$ and 1983 allow for punitive damages in addition to backpay. For a lengthy survey of the legal aspects of backpay calculation, see Special Project: Back Pay in Employment Discrimination Cases, 35 VAND. L. REv. 893 (1982); see also George A. Davidson, "Back Pay" Awards Under Title VII of the Civil Rights Act of 1964, 26 RuTGERS L. REV. 741 (1973). Note, however, that the duty to mitigate damages requires the plaintiff to look for work with reasonable diligence.

82. This method may understate a rejected worker's damages. For example, if a worker is earning rents in job $\mathbf{A}$ and is fired as a result of discrimination, she will be damaged even if she obtains another job immediately and therefore had a zero duration of unemployment. See text accompanying note 141 infra.

83. Our analysis does not require that plaintiff's legal costs are constant. We merely assume that as the wage of the job goes up, the plaintiff's costs rise less rapidly than the wage itself. Formally, we require that if $C_{p}=f(w)$, then

$$
\left(\frac{d C_{p}}{d w}\right)\left(\frac{w}{C_{p}}\right)<1
$$

84. Our analysis could be modified to account for the contingent fee structure of much Title VII litigation. In this event, the costs of bringing a lawsuit for a plaintiff are substantially reduced since attorney's fees will not have to be paid by the plaintiff in the event of a loss at trial and will be paid by the defendant in the event the plaintiff prevails. A contingency fee will not reduce the cost of litigation to zero, however, as the plaintiff obviously will not be reimbursed for his own time in seeking a lawyer and in working on the prosecution of the case. We estimate this cost to be $\$ 1,000$ in our analysis below. For an extensive analysis of differing methods of compensating plaintiffs and 
A risk-neutral potential plaintiff who maximizes expected utility will bring suit only if the expected benefits exceed the expected costs. Thus, under Title VII rules in which prevailing plaintiffs receive their costs from defendants (but not vice versa, unless the suit is found to be frivolous), ${ }^{85}$ the rule for bringing suit translates to

$$
p w D>(1-p) \times C_{p} .
$$

Notice that the left side of the equation is a function of the wage rate, but the right side is not. Holding other things (including $p$ and $D$ ) constant, an increase in the wage rate will increase the expected benefits of litigation, while leaving the expected costs unchanged, thereby encouraging potential plaintiffs to sue. We can rearrange the equation to get an expression for the critical value of the wage rate, $w^{*}$, below which rejected workers will not sue

$$
w^{*}=(1-p) \times C_{p} / p D \text {. }
$$

As an example, consider a worker who is fired from her minimum-wage job because of discrimination by her employer. Presumably, $w$ is less than $w^{*}$ for such a worker. If she sues and wins, she stands to collect a backpay award (at minimum wage) for the period between her firing and her next job. Since her wage is low and since minimum-wage jobs are relatively easy to find, she is unlikely to be unemployed for very long. Her total award, $w D$, will probably be small. If she loses, moreover, she will have to pay costs of $C_{p}$, which might easily exceed her expected gains if she wins. In sum, the better paying the job, the more likely the job-holder or applicant is to sue if rejected. ${ }^{86}$

The better jobs effect can explain an increase in employment discrimination suits, despite a constant or falling level of discrimination. As the number of "protected" workers in (or applying for) jobs that pay more than $w^{*}$ increases, with a constant amount of discrimination, more suits will be filed, since more workers now have "good" jobs that are worth suing for. Even if discrimination is decreasing, the number of suits can nevertheless rise if a higher proportion of the discriminated-against workers find it worth-

attorneys in employment discrimination cases, see Janice Madden \& Jennifer Wissink, Achieving Title VII Objectives at Minimum Social Costs: Optimal Remedies and Awards, 37 RUTGERS L. Rev. 997 (1985).

85. Defendants may recover costs only when the suit is held to be frivolous. Christiansburg Garment Co. v. EEOC, 434 U.S. 412 (1978).

86. This discussion has not specifically considered another factor that could motivate employment discrimination litigation: the interest in being "vindicated" after an adverse outcome in the labor market. A worker who was wrongly discharged might seek a legal determination that her employer acted improperly in order to maintain her self-esteem or to show potential employers that she had in fact been a good worker. The demand for vindication may be rising over time as the proportion of discriminating employers falls. A minority worker who is fired when all employers are discriminatory maintains his self-respect because everyone realizes that the employer has acted arbitrarily. As employer discrimination falls, however, the possibility that the worker is to blame for being dismissed rises, thereby elevating the need to seek vindication for discriminatory acts lest the victim be blamed for his or her own dismissal. This story is at least consistent with the observed increase in employment discrimination suits during a period of apparent decline in discriminatory attitudes. 
while to sue. 87

If we assign plausible values for $p, D$, and $C_{p}$ in the critical value wage rate equation of $.15,12.5$ weeks, and $\$ 1,000$, the value of $w^{*}$ is about $\$ 450$ per week. Any worker earning more than this amount should find it worthwhile to sue (given the other parameter values). If the plaintiff's probability of recovery rises to $.2, w^{*}$ drops to $\$ 320$. About 22 percent of all full-time wage and salary workers earned more than $\$ 450$ per week in 1986; slightly more than 60 percent of such workers earned more than $\$ 320$ per week.88 Clearly, these values are not absolute thresholds-some potential plaintifis will have a higher likelihood of victory if they sue; some may mistakenly conclude that their odds of winning are greater than they actually are; and some plaintiffs will experience longer unemployment durations, or have lower legal costs. In general, however, the better-jobs effect predicts that higher-wage workers will be over-represented among plaintiffs.

Although it is difficult to test this theory directly, the ABF survey provides some evidence. Table 4, which compares the occupational distribution of the general labor force with that of employment discrimination plaintiffs, ${ }^{89}$ shows that nonwhite plaintiffs in the sample were far more likely to be managerial/professional workers or technical/sales workers than nonwhite workers nationally. Conversely, the relatively low-paid service and agricultural workers were substantially under-represented in the sample of nonwhite employment discrimination plaintiffs.

The better-jobs effect thus attributes the rise in discrimination litigation to the increasing numbers of racial minorities and women in (or applying for) jobs paying more than the "threshold" wage necessary to bring suit. The threshold itself need not be constant over time, moreover. As the equation demonstrates, the threshold wage is a negative function of the plaintiff

87. Consider a simple algebraic example. Suppose (1) a court makes perfect decisions, so that the probability of plaintiff victory is one if the plaintiff is actually a victim of discrimination, and zero otherwise, and (2) an employee will only sue if the job from which she was rejected was a "good" one $\left(w>w^{*}\right)$. Let $T$ be the total number of rejections (firings, layofis, failures to hire, etc.) in the economy. Let $r(t)$ be the proportion of protected workers rejected from good jobs, and $x(t)$ the proportion of rejections that are discriminatory, both as functions of time. The number of suits at time $t$ will be

$$
S(t)=r \times x(t) \times r(t) \text {. }
$$

If $r$ is rising and $x$ falling over time, $S$ can either rise or fall, depending on whether the percentage rise in $r$ is greater or less than the percentage fall in $x$. That is,

$$
\begin{aligned}
\frac{d S}{d t} & =T\left[\left(x \frac{d r}{d t}\right)+\left(r \frac{d x}{d t}\right)\right] \\
& =r x T\left[\frac{d r}{d t} \frac{1}{r}+\frac{d x}{d t} \frac{1}{x}\right] \\
& >0 \text { if }\left(\frac{d r}{d t} \frac{1}{r}+\frac{d x}{d t} \frac{1}{x}\right)>0
\end{aligned}
$$

88. Telephone interview with Peter Cattan, U.S. Bureau of Labor Statistics (June 12, 1989) (notes on file with the Stanford Law Review).

89. The comparison here is somewhat clouded because the BLS figures are national while the $A B F$ data are taken from a sample of only seven cities. 
Table 4

Occupational Distribution of Nonwhite Labor Force and Nonwhite Plaintiffs in the ABF's Survey of Employment Discrimination Litigation, 1972-1987 (Column percent in parentheses)

$\begin{array}{lcc}\text { Occupation } & \begin{array}{c}\text { Nonwhite } \\ \text { Labor Force }\end{array} & \begin{array}{c}\text { Nonwhite } \\ \text { Employment } \\ \text { Discrimination }\end{array} \\ \text { Managerial/ } & 6341 & 138 \\ \text { Professional } & (15.9) & (24.0) \\ \text { Technical, Sales } & 8590 & 139 \\ & (21.5) & (24.1) \\ \text { Service } & 9153 & 91 \\ & (23.0) & (15.8) \\ \text { Agriculture } & 934 & 3 \\ & (2.3) & (0.5) \\ \text { Precision Production } & 3693 & 52 \\ & (9.3) & (9.0) \\ \text { Operator, Laborer } & 11,157 & 153 \\ & (28.0) & (26.6) \\ \text { Total } & 39,868 & 576 \\ & (100.0) & (100.0) \\ & & \\ & & \chi_{(5)}^{2}=46.75^{\mathrm{a}}\end{array}$

a. Implies rejection of the hypothesis that the distribution across occupations in the two columns is the same, using a Chi-squared test with 5 degrees of freedom (critical value at the 0.01 level is 15.09 ).

Source: National labor force data are the averages for the period 1972-1987. Distribution of plaintiffs from ABF's Survey is based on the 571 employment discrimination cases in which we could identify the plaintiff's race and occupation.

win rate $(p)$ and the duration of unemployment $(D)$. For example, the average duration of unemployment has risen substantially over the last twenty years, thereby depressing the threshold wage. ${ }^{90}$ The lower threshold wage

90. Siegelman, supra note 3, argues that the duration of average spells of unemployment plays an important role in determining the volume of litigation. Plaintiffs who are unemployed longer have larger backpay awards and thus greater expected benefits of suit. For evidence on the increase in the duration of unemployment over time, see Murphy \& Topel, supra note 15, at 25-26. 
increases the number of employees who earn more than the threshold wage, and therefore increases the number of workers who find it in their interests to sue if they perceive discrimination in hiring or firing.91

Table 5

Number of Female and Nonwhite "Managerial, Professional, and Technical" Workers, Selected Years, 1960-1988

(In Thousands)

$\begin{array}{cccc}\text { Year } & \text { Nonwhites } & \text { Women } & \text { All M,P\&T Workers } \\ 1960 & 485 & 3,587 & 12,825 \\ & & & \\ 1970 & 802 & 5,721 & 18,024 \\ & (65.36 \%) & (59.49 \%) & (40.54 \%) \\ 1980 & 1,958 & 9,767 & 26,532 \\ & (144.14 \%) & (70.72 \%) & (47.2 \%) \\ 1988 & 2,112 & 14,735 & 32,711 \\ & (7.87 \%) & (50.87 \%) & (23.29 \%) \\ & 163.4 \% & 157.9 \% & 81.4 \%\end{array}$

Numbers in parentheses are percent changes over preceding period.

Sources: U.S. BuREau of the Census, Statistical AbSTRACT of The United States: 1965, tbl. 316; U.S. Bureau of THE Census, Statistical AbSTRACT OF tHe United States: 1975, tbl. 589;

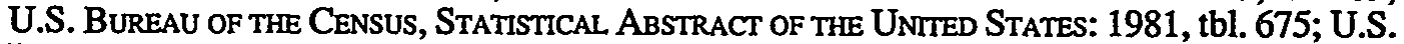

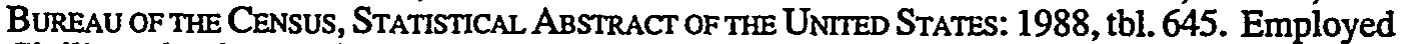
Civilians, by Occupation, Sex, Race and Hispanic Origin: 1988 (for civilian noninstitutional population 16 years old and over) pp. 389-392. Table values are based on the "Managerial and professional specialty" category and the "Technicians and related support" subcategory of "Technical, sales, and administrative support."

Some sense of the increasing access to good jobs enjoyed by minorities and women is provided in Tables 5 and 6 . Table 5 reveals that from 1970 through 1980 the number of nonwhite managerial and professional workers rose 144 percent, and the number of female managerial and professional workers rose by 71 percent. The dramatic progress of female workers continued throughout the 1980 s, although that of minorities did not. This tremendous growth in female employment in high-paying jobs is also evident in Table 6.92 Twenty years ago, only 5 percent of graduates from law, medical,

91. We already calculated the effect of the higher unemployment rate on the increase in employment discrimination cases. See notes 14-17 supra and accompanying text. To the extent that the increased duration of unemployment correlates with the increased unemployment rate, it is reflected in Table 2.

92. While there has been only modest movement by women out of low-paying jobs, there has been immense movement by women into high-paying jobs. If women who had previously been 
and business schools were female, while today, 25 percent of all new M.D.s and M.B.A.s, and 33 percent of new J.D.s are women. ${ }^{93}$

Table 6

Representation of Women in Ten High-Paying and Ten Low-Paying Occupations, 1970 and 1981

Percent Female

Occupation

1970

1981

High-paying

Stock and bond sales agents

8.6

17.1

Managers and administrators, n.e.c. ${ }^{a}$

11.6

19.6

Bank officials and financial managers

17.4

36.5

Sales representatives, manufacturing

8.5

16.0

Designers

23.5

23.9

Personnel and labor relations workers

31.2

48.7

Sales representatives, wholesale

6.4

10.7

Computer programmers

22.7

28.4

\section{Low-Paying}

Practical nurses

96.3

97.3

Hairdressers and cosmetologists

90.4

85.3

Cooks, except private household

\begin{tabular}{l}
$62.8 \quad 50.9$ \\
\hline
\end{tabular}

Health aides, except nursing

83.9

82.7

Nurses' aides

84.6

84.3

Sewers and stitchers

93.8

96.7

Farm laborers

13.2

12.3

Child-care workers, except

private households

All occupations

a. not elsewhere classified.

Source: Robert J. Flanagan, LaWrence M. Kahn, Robert S. Smith, \& RONALD G. EHRENBERG, ECONOMICS OF THE EMPLOYMENT RELATIONSHIP 203 (1989).

\section{The "integration" effect.}

Job upgrading not only increases the incentives for bringing an employ-

teachers (and who presumably earned more than the average female) are shifting into upper-tier jobs, then female median earnings might not rise. This may in part explain why relatively little improvement has occurred in the female/male ratio of median earnings even as women advance into high-paying employment.

93. James P. Smith \& Michael Ward, Women in the Labor Market and in the Family, $3 \mathrm{~J}$. ECON. PERSP. 9, 17 (1989). 
ment discrimination suit, but it also significantly affects the ability of workers to detect discrimination in the first place. White males have historically held better-paying jobs than both minorities and women. But as

women [and minorities] are more likely to be in occupations that contain [white] men, a larger number of them [women and minorities] will ... have a readily accessible [white] male against whom they can measure their labor market success, particularly in dimensions not measured in [data on wage differences]. Thus they will have more nonstatistical evidence of discrimination without necessarily being more discriminated against according to the standard statistical measures. ${ }^{94}$

Both the legal and the common sense definitions of discrimination are relative: Discrimination occurs when blacks are treated differently from whites, or women differently from men. Without reference groups against which blacks or women can judge their own treatment by employers, discrimination is more difficult both to detect and to prove.

Our review of a number of employment discrimination cases reveals a common fact pattern: A worker is fired as part of a reduction in force or because of some alleged individual misconduct such as tardiness. The worker then alleges that workers of the opposite race or gender were either less productive or even more guilty of the alleged offense but were not fired. ${ }^{95}$ If the firm had been completely segregated, this comparative evidence of discrimination would not have been available. ${ }^{96}$ Integrating the work force by race and gender, then, is likely to produce more evidence and allegations of discrimination, even if the incidence of discrimination itself is falling. ${ }^{97}$ Due to the increased awareness of relative mistreatment, discrimination in an integrated firm may be more personally harmful than general discrimination against an entire group in a segregated firm. ${ }^{98}$

94. Kuhn, supra note 25 , at 579.

95. Barbara Lindemann Schlei \& Paul Grossman, Employment Discrimination LAw (2d ed. 1983 \& Supp. 1989) (suggesting that this pattern is common and citing several cases in which the existence of discrimination turns on whether white and nonwhite employees were treated identically); see, e.g., Alexander v. Gardner-Denver Co., 519 F.2d 503 (10th Cir. 1975) (black plaintiff alleged that white employees who made equal or greater amounts of scrap were not given pink slips); Martin v. Chrysler Corp., 10 Fair Empl. Prac. Cas. (BNA) 329, 9 Empl. Prac. Dec. (CCH) f 10,066 (E.D. Mich. 1974) (black production worker alleged he was discharged for falsifying his work count while white workers who falsified their work counts were not discharged). Courts, as well as plaintiffs, often seem to view discrimination in this way. See, e.g., McDonnell Douglas Corp. v. Green, 411 U.S. 792 (1973) (employer's allegedly dissimilar treatment of whites and blacks is relevant to assessing whether stated reason for failing to hire a black applicant was pretextual).

96. The examples we have used to illustrate the effect of integration are consistent with either a story that the firing was discriminatory and integration provided the compelling proof, or that the firing was actually nondiscriminatory but integration provided a basis for challenging the action by raising the issue of the relative ability of the fired worker versus a retained worker of the opposite race.

97. To the extent that integration of the work force by race and sex is proceeding fastest with young workers, we would expect young workers to have more opportunity to perceive discrimination than older workers who work predominantly in segregated settings. Therefore, we may have accounted for at least some of the integration effect in computing the size of the cohort effect. See text accompanying notes $25-35$ supra.

98. Robert H. Frank, Choosing the Right Pond (1985); Robert H. Frank, Are Workers Paid Their Marginal Product?, 74 AM. ECON. REv. 549 (1984); Robert H. Frank, Interdependent 
Table 7 provides evidence of the increasing integration of the work force. The Duncan index of occupational segregation assumes values from zero (representing full integration) to 100 (representing complete segregation). ${ }^{99}$ Note that, while occupational segregation between women and men in general declined considerably between 1960 and 1980, the greatest declines occurred at the highest education levels. Interestingly, the last two lines of Table 7 show that occupational segregation by race declined much more than segregation by sex.

If integration leads to more suits, other things remaining equal, then one would expect states with lower Duncan index values (that is, more integration) to have more employment discrimination lawsuits. ${ }^{100}$ Peter Siegelman's dissertation demonstrates that this is in fact the case: Even after controlling for differences in minority populations and unemployment rates, and correcting for unobserved levels of discrimination across states, the Duncan index of racial segregation is negatively and statistically significantly related to the volume of litigation. ${ }^{101}$

The evidence presented in Tables 5 and 6 suggests that, in the period following 1970, women may have had somewhat greater success than minorities in entering the "better" jobs. If our better-jobs theory is correct, this fact would imply faster growth in sex discrimination than race discrimina-

Preferences and the Competitive Wage Structure, 15 RAND J. Econ. 510 (1984). Robert Frank draws on biology, sociology, and economics to argue persuasively that relative standing (position visà-vis peers) is an important variable in people's utility functions. Frank demonstrates that in practice the "reference group" in determinations of relative position is typically close co-workers or neighbors, rather than a larger entity such as city or region. If Frank is correct, employment discrimination which lowers a person's relative standing is not only more observable but actually more salient (costly) than discrimination which leaves no one worse off relative to the reference group. In other words, if nonwhite workers are given identically bad treatment both in a completely segregated firm and in an integrated firm (in which whites are treated better), the nonwhite workers may feel worse about their bad treatment in the integrated firm.

99. The Duncan index is calculated by summing one-half the absolute differences in the percent of employed men and the percent of employed women in different occupations. That is,

$$
\mathrm{D}=100 \times \sum_{i} \frac{\left|m_{i}-w_{i}\right|}{2}
$$

where $m_{i}$ is the number of men employed in industry $i$ divided by the number of men employed in all industries, and similarly for w. Victor R. Fuchs, Women's Quest for Economic Equality, $3 \mathrm{~J}$. EcoN. PERSP. 25, 26 (1989).

The Duncan index data merely suggest increased integration and do not demonstrate conclusively that integration is occurring. For example, if the proportion of female lawyers rose to exactly $50 \%$ (thereby causing the Duncan index to drop), but all female lawyers worked in all-female law firms, there would be no effective integration among male and female lawyers. In addition, the general problem of what constitutes the appropriate reference group for measuring integration - the industry, firm, or even job category within the firm-is an extremely difficult one.

100. Integration of work places by race and sex can also generate frictions that may lead to litigation. For example, in Robinson v. Jacksonville Shipyards, 1991 U.S. Dist. LEXIS 794 (1991), one of the few female welders employed at a shipyard successfully complained of a hostile work environment because of the "presence in the workplace of pictures of women in various stages of undress and in sexually suggestive or submissive poses." Id. In all likelihood, such pictures would not generate litigation in an all-male work force.

101. The exact details of the panel data estimation procedure that yielded this result are in Siegelman, supra note 3. Interestingly, the male/female Duncan index was not correlated with the volume of litigation. 
Table 7

Duncan Index ${ }^{a}$ of Occupational Segregation

by Sex and by Race

$\begin{array}{llll} & & \text { Change from } \\ \text { Computed by gender } & 1960 & 1980 & 1960 \text { to } 1980\end{array}$

\begin{tabular}{ccccc}
$\begin{array}{c}\text { Women:Men } \\
\text { white } \\
\text { black }\end{array}$ & & 62 & 57 & -5 \\
\multirow{4}{*}{ Age } & $25-30$ & 67 & 57 & -14 \\
& $35-44$ & 63 & 55 & -12 \\
& $45-54$ & 63 & 60 & -5 \\
& $55-64$ & 65 & 61 & -3 \\
& & & & -4
\end{tabular}

Education no more than:

$\begin{array}{llll}\text { no high school } & 66 & 60 & -6 \\ \text { some high school } & 64 & 61 & -3 \\ \text { high school diploma } & 66 & 62 & -4 \\ \text { college degree } & 66 & 50 & -16 \\ \text { graduate degree } & 56 & 43 & -13\end{array}$

Computed by Race

White:Black

$\begin{array}{llll}\text { women } & 56 & 28 & -28 \\ \text { men } & 50 & 33 & -17\end{array}$

a. The Duncan Index equals 0 under perfect integration and 100 under perfect segretation.

Source:VictorR.Fuchs, Women's Questfor Economic Equality,3J.EcoN. PerSP. 25, 27 (1989).

tion cases. On the other hand, the evidence in Table 7 suggests that the integration effect would give greater impetus to race discrimination cases rather than sex discrimination cases. In fact, the percentages of race and sex discrimination cases remained fairly constant over this period, at about 50 percent and 33 percent, ${ }^{102}$ respectively, suggesting that the better-jobs effect and the integration effect may have been in equipoise.

\section{Conclusion.}

In conclusion, the better-jobs and integration effects have an ironic aspect: The attainment of better and more integrated jobs for minorities is clearly a major goal of antidiscrimination laws, but society's very success in

102. ABF Survey, supra note 3; EEOC, supra note 3. 
meeting this goal has contributed to a sizable increase in employment discrimination lawsuits. Improvements in the workplace have spawned strife in the courtroom.

But one might challenge our observations as reversing cause and effect: Rather than the increased access of minorities and women causing an increase in Title VII lawsuits, perhaps it is the increased litigation that has catalyzed employment gains for minorities and women. While Title VII did initially open many areas to minorities that previously had been foreclosed, the nature of Title VII litigation has shifted dramatically over time, indicating that the subsequent explosion in Title VII cases is caused by and not the cause of improved labor market experience.

\section{The ShIFt IN THE NATURe OF EMPLOYMENT DISCRIMINATION LITIGATION}

Assuming that concrete improvements have occurred, one might expect to see a significant shift in the nature of employment discrimination cases as minorities and women no longer need to complain about blanket exclusions from good jobs-that battle has, by now, largely been won-but now complain more commonly of being fired from these better jobs. Indeed, the evidence suggests that just such a shift has occurred. Figure 6 charts the number of hiring and termination ${ }^{103}$ charges brought before the EEOC. The figure shows a dramatic divergence in the pattern of hiring and termination charges. Hiring charges outnumbered termination charges by 50 percent in 1966, but by 1985, the ratio had reversed by more than 6 to 1 . The ABF survey results illustrated in Figure 7 confirm the EEOC data: 19 percent of suits alleged discrimination in hiring, while 59 percent alleged discrimination in discharge. Moreover, the pattern of allegations over time is consistent with that observed in the EEOC data. The volume of hiring and termination charges was roughly similar in the early years but diverged sharply by $1986 .{ }^{104}$

What accounts for this dramatic change in the composition of litigation? No divergence in the legal standards for proving discrimination in hiring as opposed to firing cases occurred during this period. ${ }^{105}$ Nor were there any

103. We use "termination" to refer to both discriminatory discharge and to layoff. The EEOC treats these categories separately.

104. The dramatic shift in the focus of employment discrimination litigation from hiring to firing cases also raises doubts about the view that the increase in litigation is due largely to increased rent-seeking. If rent-seeking were the explanation, one would expect a growth in both hiring and firing cases. Indeed, a rent-seeking litigant could apply to many different employers and file discrimination charges against all of them, while firing charges can only be brought against employers for whom the plaintiff has actually worked.

But Figures 6 and 7 show that the number of hiring cases has declined. Perhaps as the number of actual and perceived discriminatory refusals to hire falls, the likelihood of obtaining favorable outcomes through rent-seeking litigation falls as well. For example, it may have been easier for a black plaintiff to prevail on a rent-seeking claim against the Alabama Highway Patrol for refusal to hire when no blacks were employed by the Highway Patrol than when blacks were more fully represented in that job.

105. B.L. SCHLEI \& P. GRosSMAN, supra note 95, at 5. "[N] umerous courts have continued to 


\section{Figure 6}

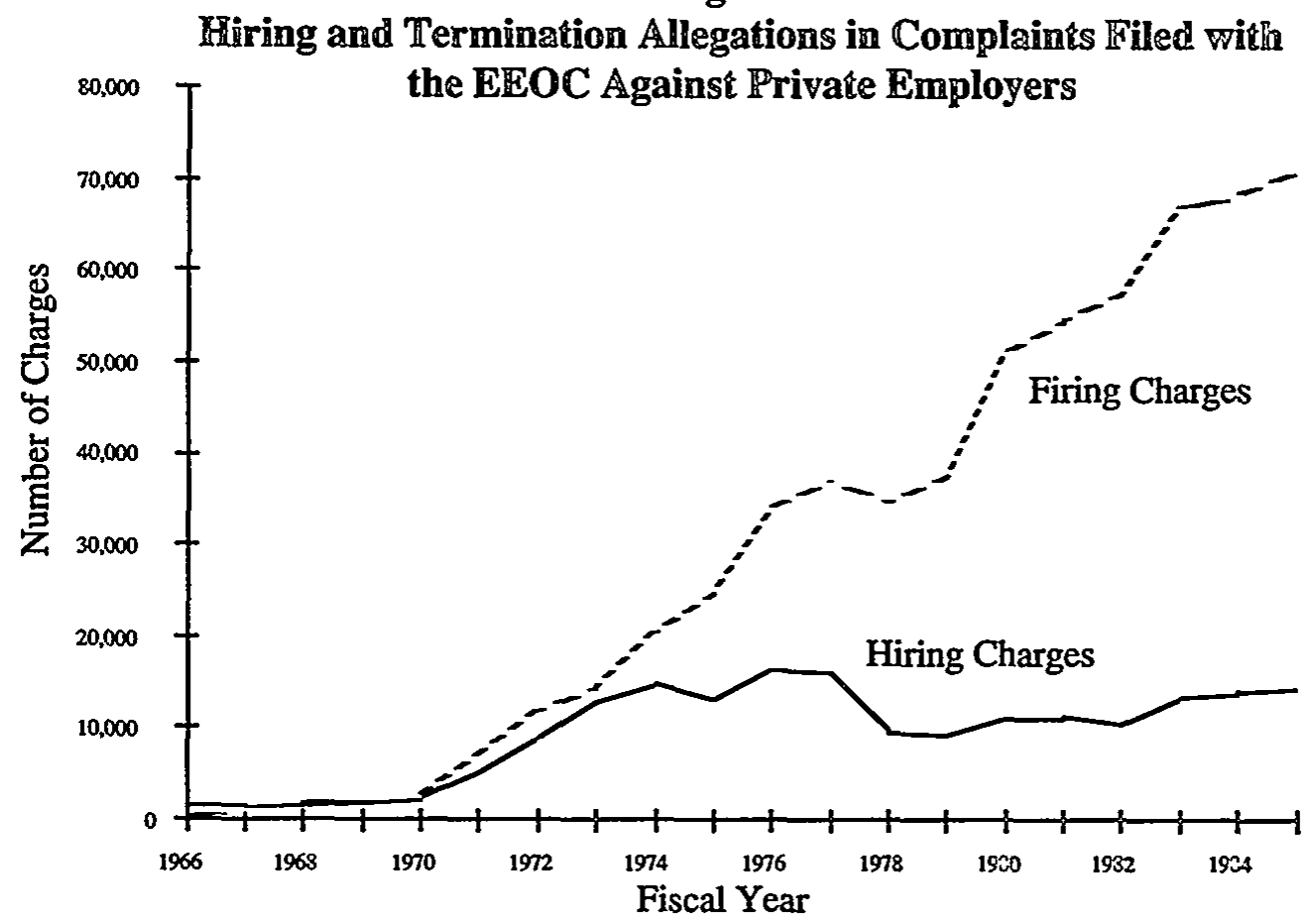

Source: 1966-1985 EEOC ANN. REP.

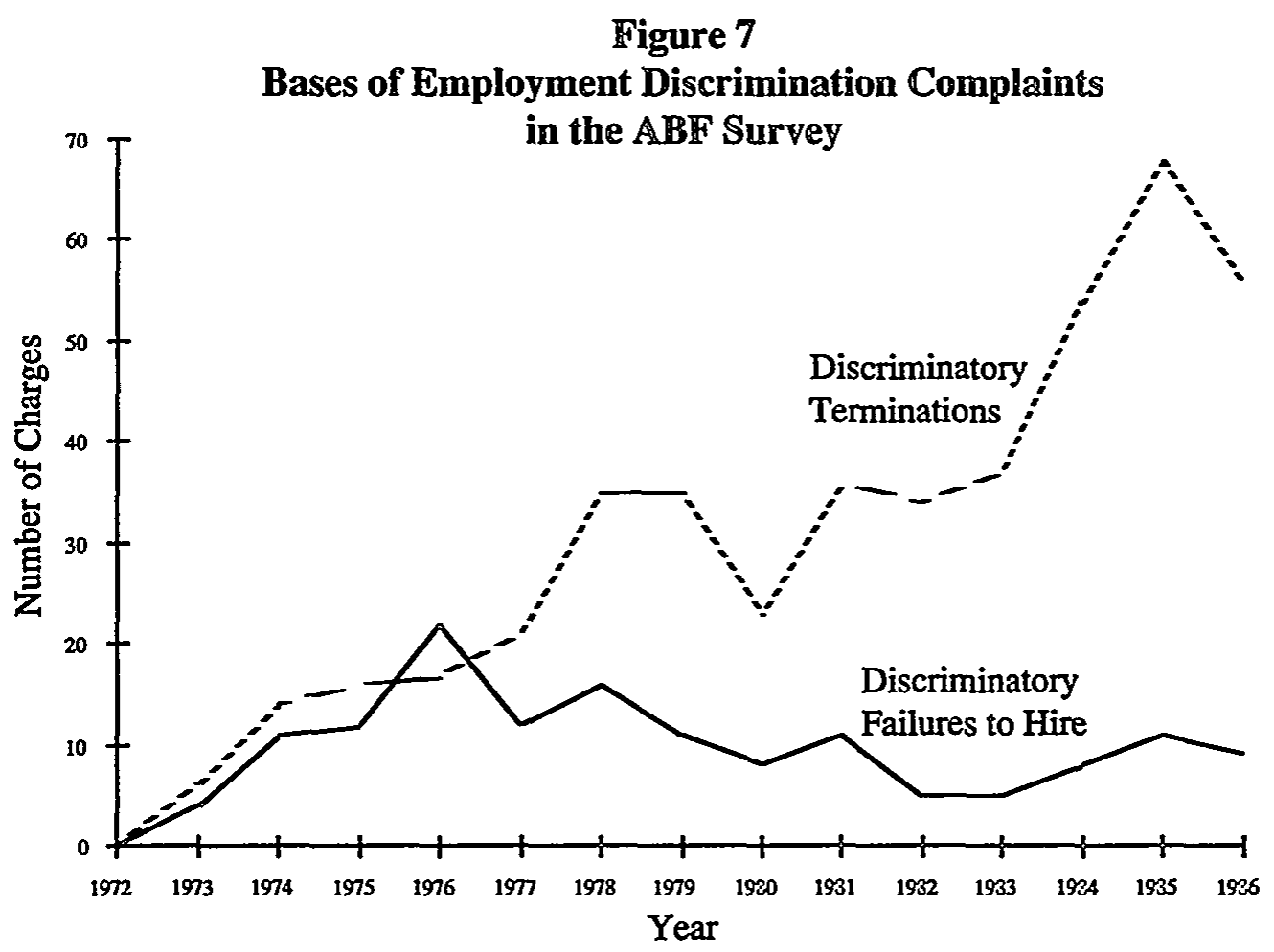

Source: American Bar Foundation Employment Discrimination Litigation Survey, Computer File (1990) (on file with the authors). 
differences in the calculation of damages for the two kinds of discrimination. Once again, therefore, we look outside the legal system to explain the shifting composition of litigation.

\section{A. Dispelling Some Explanations for the Shift}

\section{Has discrimination in hiring decreased and discrimination in firing increased?}

We have argued that the likelihood of filing employment discrimination complaints-whether based on actual discrimination, perceived discrimination, or rent-seeking-will rise as women and minorities move into better and more integrated jobs. But if such employment improvements are real, we would expect that certain types of cases would be brought less often or would be less likely to succeed. For example, as women and minorities obtain greater access to better jobs, the number of actual and perceived discriminatory refusals to hire would presumably decline. Yet this presumption does not apply equally to actual or perceived cases of discrimination in firing.

Claims that employer animus exists in termination but not in hiring seem irrational: It hardly makes sense to hire workers from a group one dislikes (thereby incurring the psychological costs of associating with them), only to fire them once they are on the job. ${ }^{106}$ Such behavior seems doubly irrational given that the expected penalties for terminating a worker are probably much higher than for failing to hire her. ${ }^{107}$

apply the order and allocation of proof set forth in McDonnell Douglas v. Green to discharge cases." Id. (citing McDonald v. Santa Fe Trail Transportation Co., 427 U.S. 273, 281-85 (1976); Flowers v. Crouch-Walker Corp., 552 F.2d 1277, 1281-82 (7th Cir. 1977)).

106. The model of animus-based employer discrimination was initially set forth in GARY S. BECKER, THE ECONOMICS OF DISCRIMINATION (2d ed. 1971). One can imagine scenarios in which the behavior described in the text would make sense. For example, since 1966, any firm with 100 or more employees or any major government contractor has been required to file a report with the EEOC on the composition of their work force by race and sex for nine broad occupational categories. See Orley Ashenfelter \& James Heckman, Measuring the Effect of an Antidiscrimination Program, in Evaluating the Labor-Market Effects of Social Programs 46, 54 (O. Ashenfelter \& J. Blum eds. 1976). If employers wanted to "look good" on the EEOC report, they might hire a number of minority employees just before filing and subsequently fire them. Presumably, though, this behavior would quickly attract attention and is therefore unlikely to be widespread. After examining some preliminary data on turnover rates of women and blacks, Jonathan Leonard concluded that "establishments do not run a revolving door policy when it comes to compliance reviews." JonAthan LeONARD, The IMPACr OF AfFiRMative ACTION 140 (1983).

Alternatively, new management may wish to eliminate protected workers hired under a previous regime. This explanation is unconvincing, though, since new management should be less prejudiced than its predecessor: Non-profit-maximizers such as discriminators make ideal takeover targets for profit-maximizing (non-discriminating) acquirers.

107. Presumably, the damages for either type of Title VII action would be roughly comparable, subject to one caveat: If workers build up significant specific human capital that enables them to earn more with their current employer than they could earn with a new employer, the damages from discriminatory discharge would be greater than for discriminatory refusals to hire. Nonetheless, the expected damages for a discriminatory discharge are far greater than for a discriminatory failure to hire because there is a far greater likelihood of being sued by a discharged employee than by a rejected applicant. See text accompanying notes 103-104 supra. Even if we conservatively assume that the number of instances of discrimination in hiring equals the number of instances of discrimi- 


\section{Has non-animus-based discrimination increased?}

Not all employment discrimination, however, is based on animus. Nonanimus-based discrimination might also be consistent both with increasing discriminatory behavior in terminations and the absence of discrimination in hiring by rational employers. For example, the ADEA's definition of discrimination includes replacing an older worker with a younger, equally productive worker who receives a lower salary. ${ }^{108}$ (The employer's motivation presumably is a cost savings to the firm and not an aversion to associating with older workers.) Therefore, an employer might rationally "discriminate" by terminating older employees without discriminating in hiring (especially if no older workers apply for posted job openings).

Table 8

Age Discrimination in Employment Act Allegations Filed with the EEOC, as a Percent of all EEOC Filings

$\begin{array}{cc}\text { Year } & \text { Percent } \\ & \\ 1980 & 18.7 \\ 1981 & 14.4 \\ 1982 & 17.0 \\ 1983 & 21.8 \\ 1984 & 17.5 \\ 1985 & 18.9 \\ 1986 & 20.1 \\ 1987 & 18.7 \\ & \\ \text { Average } & 18.4 \\ & \\ \text { Standard } & \\ \text { Deviation } & 2.0\end{array}$

Evidence suggests, however, that this form of age discrimination has not significantly contributed to the increase in discriminatory termination claims. The EEOC's data on employment discrimination charges in Table 8 show that the proportion of ADEA charges received by the EEOC has not increased since 1980 (the earliest year for which we have data). ${ }^{109}$ Moreover, since ADEA charges comprise only about 18 percent of the EEOC's annual volume of charges, ${ }^{110}$ their behavior over time cannot be responsible

nation in firing, then the probability of being sued for the latter violation is roughly six times as great. See text following note 133 infra.

108. See 29 U.S.C. \& 623(a)(1) (1988).

109. The EEOC did not have jurisdiction over ADEA cases until 1978. These figures were first available for 1980 .

110. EEOC, supra note 3. The ADEA cases comprise presumably less than $18 \%$ of all employment discrimination cases, since due process and $\$ \S 1981$ and 1983 employment discrimination cases are not processed through the EEOC. 
for the dramatic increase in firing cases since 1969.

The ABF Survey of employment discrimination litigation confirms that nonanimus-based discrimination is not responsible for the shift from hiring to firing claims. Of the 997 employment discrimination cases in which we could identify the type of discrimination alleged, 888 ( 89 percent) were animus-based, 103 (10 percent) were statistical- or market-based, and 6 (1 percent) were both. ${ }^{111}$ Clearly, claims of non-animus-based discrimination constitute too small a fraction of the total volume of lawsuits to explain the enormous growth in termination cases.

\section{The effect of the decline in unionization.}

One function that unions perform is to provide a grievance mechanism to handle claims of wrongful discharge. As the number of workers covered by such union protection shrinks, more discharge cases ought to end up in federal court framed as employment discrimination suits. This factor has undoubtedly contributed to the observed growth in Title VII discharge cases, although it offers no explanation for the decline in the number of hiring cases when computed on a per worker basis.

\section{B. The Decline of the Class Action Lawsuit}

Figure 8 demonstrates another important change in the nature of employment discrimination litigation. The class action lawsuit, once a mainstay in the effort to enforce civil rights in the workplace, ${ }^{112}$ has virtually vanished from the scene. Only 51 requests for class certification in employment discrimination cases were filed during FY 1989, down nearly 96 percent from a peak of 1106 in FY 1975.

While changes in legal rules have been responsible for only about 30 percent of the total increase in employment discrimination litigation, ${ }^{113}$ they probably explain a far greater proportion of the decline in class actions. Evidence comes from both the timing and the magnitude of the decline. If a fall in hiring discrimination were responsible for the drop in class action requests, the drop would have occurred earlier and more gradually than Figure 8 indicates. One possibility is that the pattern is an artifact of the Administrative Office's coding scheme, although extensive discussions with those involved do not support this hypothesis. An alternative is that the falloff reflects changes in legal doctrine that occurred in 1977 and 1982, when the Supreme Court considerably tightened the standards for class action certification in employment discrimination cases. ${ }^{114}$ This too is only a partial explanation since the changes in doctrine occurred after the downward trend

111. ABF Survey, supra note 3. Note that we treat sexual harassment as animus-based.

112. See, e.g., Robert Belton, A Comparative Review of Public and Private Enforcement of Title VII of the Civil Rights Act of 1964, 31 VAND. L. Rev. 905, 934 (1978) ("The development of the Title VII class action was critical in the private enforcement efforts.").

113. See text accompanying notes 39-62 supra.

114. East Texas Motor Freight System, Inc. v. Rodriguez, 431 U.S. 395 (1977) (employment discrimination not inherently discrimination against a class, and not exempt from FED. R. CIV. P. 23 


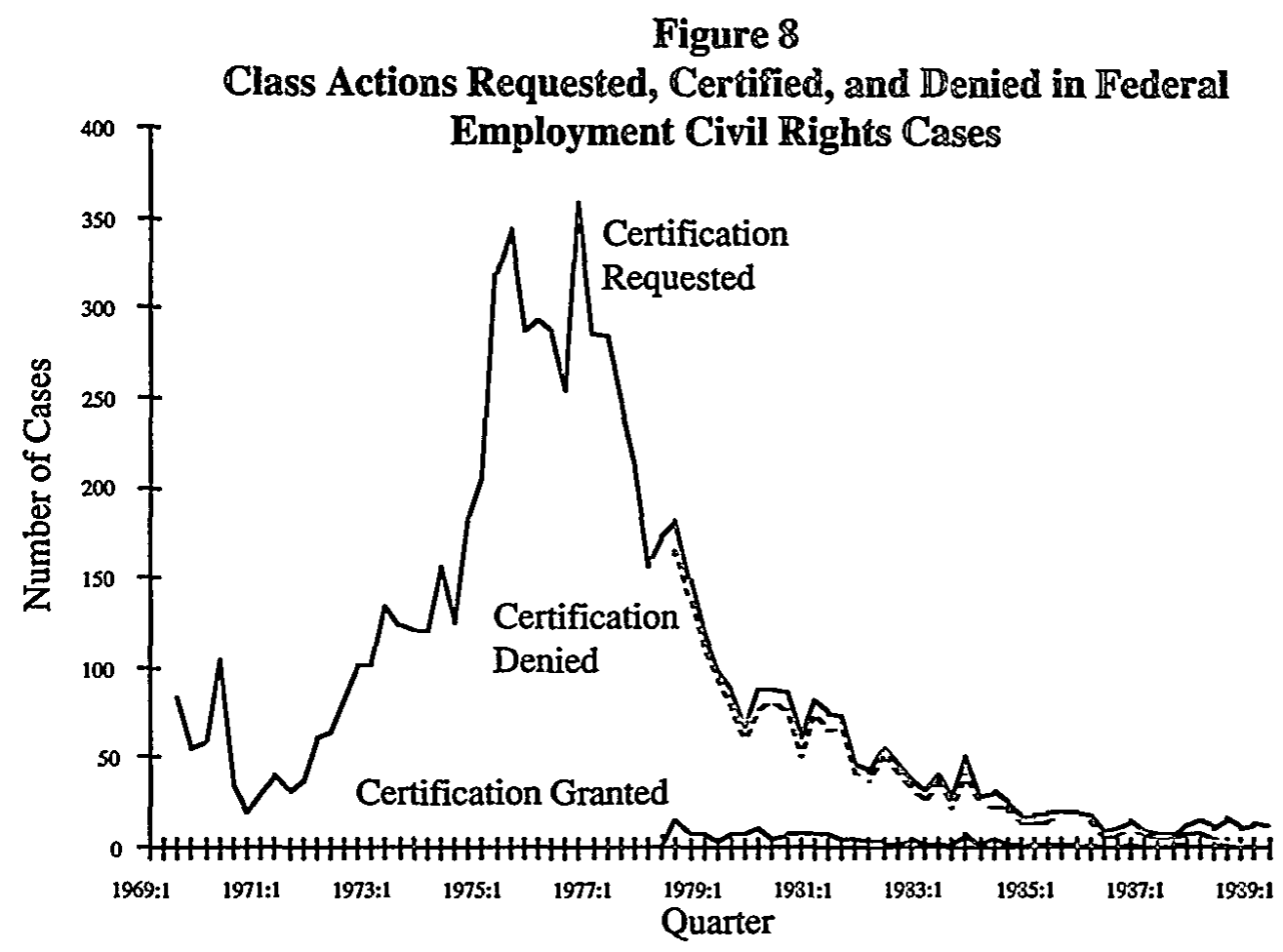

Source: Administrative Office of the U.S. Courts, Computer File (1989) (on file with the authors). Note that data on outcomes of class certification requests are for cases with closing dates after the second quarter of 1978 .

Figure 9

Class Action Requests by Non-U.S. Government Plaintiffs Employment Civil Rights and All Other Categories

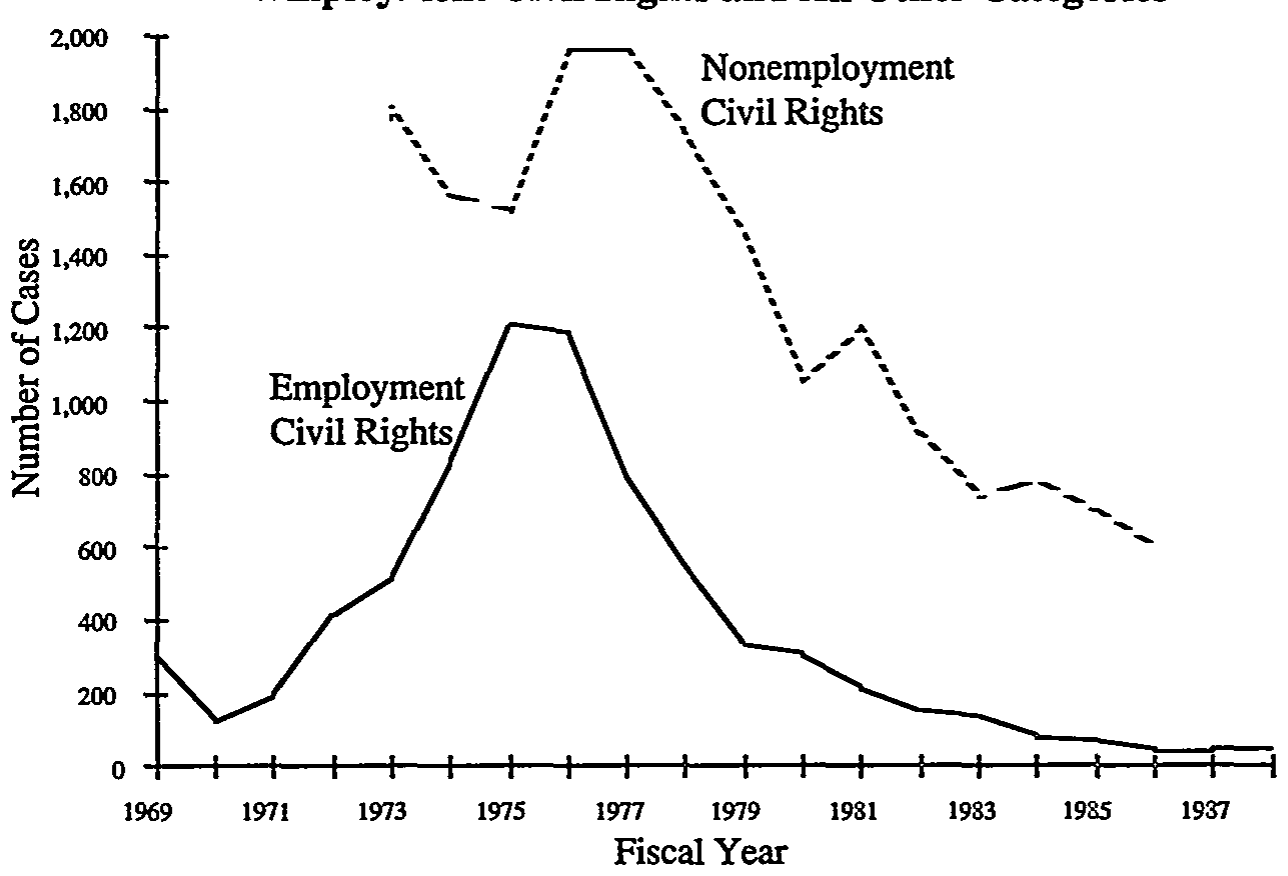

Sources: Administrative Office of the U.S. Courts, Computer File (1989) (on file with the authors); 1966-1985 EEOC ANN. REP. 
in the volume of filings had already begun. Finally, developments outside of the employment discrimination context (such as changes in the rules governing attorneys' fees, notification, etc.) may have been responsible for some of the decline. Paul Carrington, official reporter of the Federal Rules of Civil Procedure, remarked recently that "class actions had their day in the sun and kind of petered out."115 This explanation is supported by Figure 9, which plots the annual volume of non-U.S. Government plaintiff class actions in employment civil rights cases and in all other federal civil cases. A clearly apparent parallel decline in both kinds of litigation suggests that the declining use of class actions in employment discrimination suits is part of a larger trend in the use of class actions in all contexts.

\section{Conclusion: Legal and Policy Implications}

This section discusses the broad implications of our findings for the way we understand antidiscrimination law.

\section{A. Predicting Future Employment Discrimination Caseload Growth}

Employment discrimination litigation has increased dramatically over the last two decades. Projections of the future caseload based on simple extrapolations of this trend can generate alarming predictions: If the volume of litigation continues to grow at the same 16.8 percent per year average rate it did between 1969 and 1989, we will see one suit per currently employed worker-roughly 125 million suits-by the year 2053.116 This example reveals the absurdity of extrapolating the current trend far beyond its base period. Nevertheless, the employment discrimination workload imposed on judges and the fear that this caseload will continue to grow have already given the Federal Courts Study Committee cause to recommend that these claims should be dealt with administratively where feasible. ${ }^{117}$

A number of factors temper these ominous growth predictions, however. First, to the extent that the country can maintain relatively low unemployment rates, a potent stimulant of employment discrimination cases will be removed. ${ }^{118}$ Second, the quadratic component of the time trend in Table 1 suggests that the upward trend is already slowing. This is to be expected as

certification requirements); General Telephone Co. v. Falcon, 457 U.S. 142 (1982) (proof of individual discrimination not adequate to certify a class action).

115. Douglas Martin, The Rise and Fall of the Class-Action Lawsuit, N.Y. Times, Jan. 8, 1988, at B7, col. 3 .

116. The figure was derived by solving for $n$ in the equation:

where

$$
S_{\delta 9} \times(1+r)^{n}=125 \text { million }
$$

$S_{\delta \supset}=$ number of suits in $1989=7613$,

$r=$ annual growth rate of employment discrimination litigation $=16.8 \%$,

$n=$ number of years until volume of suits reaches 125 million.

The negative coefficient on the quadratic term of the regression equation presented in Table 1, supra, confirms that the growth in the employment discrimination caseload is slowing and will ultimately become negative if the present trend continues.

117. Federal CouRTS STUdy CoMmitTeE, supra note 1, at 49-51.

118. See text following note 8 supra. 
the rising number of cases prompts employers to change their behavior so as to reduce perceived discriminatory conduct or the probability of success at trial for plaintiffs. Finally, the increasingly conservative federal judiciary has already pruned some pro-plaintiff antidiscrimination law. Specifically, the Supreme Court, evincing a growing disenchantment with affirmative action, has recently restricted the reach of federal statutes designed to attack discrimination, ${ }^{119}$ increased the burden on plaintiffs relying on statistical evidence to establish that employers are discriminating on the basis of race or sex, ${ }^{120}$ and imposed higher procedural barriers on plaintiffs seeking to challenge discriminatory employment practices. ${ }^{121}$ This has undoubtedly caused some litigants to pursue remedies under state antidiscrimination laws and state wrongful discharge rules (especially those permitting punitive damage awards) where possible. ${ }^{122}$ On the other hand, while the executive and judicial branches are less enthusiastic about the benefits of vigorous antidiscrimination efforts than in earlier years, the Congress seems to have reached new heights of enthusiasm. It is considering not only reversing some recent Supreme Court decisions ${ }^{123}$ but also expanding the reach of Title VII beyond anything previously seen. ${ }^{124}$ An expansion of federal antidiscrimination law might well set off a new round of rapid growth in the employment discrimination caseload, followed by behavioral responses of employers that would over time tend to erode this growth. Indeed, this is the very fear articulated by opponents of the new legislation: that the invigorated dispa-

119. See Patterson v. McLean Credit Union, 491 U.S. 164 (1989) (§ 1981 cannot be used to challenge conditions of employment, such as racial harassment); Jett v. Dallas Indep. School Dist., 491 U.S. 701 (1989) (public authorities will not be responsible under the doctrine of respondeat superior for the $\S 1981$ violations of their officials).

120. Wards Cove Packing Co. v. Atonio, 490 U.S. 642 (1989) (burden of proving a Title VII violation under a disparate impact theory remains with the plaintiff, and employer can prevail if there is merely a reasoned basis-not necessarily a business necessity-for the challenged practice). Wards Cove reversed some elements of the most important case interpreting Title VII, Griggs v. Duke Power Co., 401 U.S. 424 (1971), which held that educational and testing requirements that screened out higher proportions of minorities than whites, and which were not necessary for job performance, violated Title VII regardless of the employer's intent. The Supreme Court extended Griggs to sex discrimination in 1977, Dothard v. Rawlinson, 433 U.S. 321 (1977), and in 1988 to subjective practices that had a disparate impact on minorities, Watson v. Fort Worth Bank \& Trust, 487 U.S. 977 (1988).

121. Lorance v. AT\&T Technologies, 490 U.S. 900 (1989) (women who were demoted a number of years after a change in a seniority system that made the demotion possible could not challenge their demotion because they had failed to complain within 180 days of the seniority change, which the Court deemed to be "the alleged unlawful practice"). At the same time, the decision in Martin v. Wilkes, 490 U.S. 755 (1989), which encourages white employees to challenge affirmative action plans designed to aid minorities will likely generate a significant number of lawsuits.

122. For example, the more generous remedies under California's wrongful discharge law probably encourage litigants to sue in state rather than federal court. Recognition of exceptions to the employment at will doctrine in a state's courts has lowered the volume of federal employment discrimination litigation in that state. See Siegelman, supra note 3, at 123-24, 139.

123. If enacted in its form as of this writing, the Civil Rights Act of 1991 will reverse the Supreme Court decisions in Patterson and Wards Cove.

124. The version of the Civil Rights Act of 1990 that was passed by Congress but vetoed by President Bush would for the first time have permitted punitive damages for intentional violations of federal antidiscrimination law. S. 2104, 101st Cong., 2d Sess. §8(a) (1990). 
rate impact doctrine Congress seeks to enact will force employers to hire by quota to escape liability. ${ }^{125}$

\section{B. The Deterrent Effect of Private Litigation}

The efficacy of Title VII and many other federal antidiscrimination laws depends primarily on the willingness and ability of workers to bring private suits challenging discriminatory employment practices. ${ }^{126}$ The law provides an incentive to end discriminatory behavior by making such behavior costly to employers; but if discrimination victims never sue, then employers have no economic incentive to comply. ${ }^{127}$ More generally, if enforcement is left in the hands of private litigants, and if private and social incentives to bring suit differ, the system may fail to produce the optimal amount (and perhaps the optimal composition) of litigation. ${ }^{128}$ Thus, one might question whether relying on individual citizens to bring suits is the most effective enforcement strategy. On one hand, Paul Burstein and others have pointed out that civil rights opponents intended the private enforcement mechanism as a deliberate road-block to plaintiffs' effective pursuit of their rights, especially given that "many of those discriminated against would be poor and legally unsophisticated." 129 On the other hand, Alfred Blumrosen offers a substantially different interpretation. Writing in 1971, Blumrosen claimed that

The crucial innovation in the 1964 Civil Rights Act was the enlargement of the role of the individual right to sue in the federal courts, rather than the enhancement of administrative agency powers .... The decision to prefer the courts over the administrative process was sensible, in light of the quarter century of failures by state and federal administrative agencies ....

The decision to establish an individual right to sue rather than to expand the role of administrative agencies was a political compromise between "lib-

125. See Crovitz, supra note 56.

126. Congress gave private individuals a significant role in the enforcement process of Title VII . . . . And although the 1972 amendment to Title VII empowers the [Equal Employment Opportunity] Commission to bring its own actions, the private right of action remains an essential means of obtaining judicial enforcement of Title VII. In such cases, the private litigant not only redresses his own injury but also vindicates the important congressional policy against discriminatory employment practices.

Alexander v. Gardner-Denver Co., 415 U.S. 36, 45 (1974) (citation omitted). For a discussion of the EEOC's relatively small role in enforcement, see texts accompanying notes 37 \& 66-67 supra.

127. Of course, the pressures of the other federal antidiscrimination programs remain, such as the government contract compliance program. Moreover, reputation considerations and market pressures will discipline inefficient discrimination to some degree. For an evaluation of studies exploring the effects of the contract compliance program, see Donohue \& Heckman, supra note 72, at 27-31.

128. For a treatment of these issues (including litigation costs, social versus private incentives to sue, and non-suing potential plaintiffs) that is skeptical about the efficiency of the outcome, see KeITH N. Hylton, Litigation Costs AND the ECONOMIC TheORY OF TORT LAW (American Bar Foundation Working Paper No. 9011, 1990).

129. P. Burstein, supra note 69, at 28; cf. KRISTIN BUMILler, THE CIVIl Rights SOCIETY (1988) (arguing from a critical theory perspective that private enforcement further victimizes the victims of discrimination and therefore is inherently incapable of reducing the problem it is designed to address). For a somewhat more optimistic evaluation of the mobilization of EEOC law, see Paul Burstein \& Kathleen Monaghan, Equal Employment Opportunity and the Mobilization of Law, 20 LAW \& SOC'Y REV. 355 (1986). 
erals" who wished to create an all-powerful administrative agency and "conservatives" who objected to the creation of such a bureaucracy. The compromise... may have created the most effective possible arrangement for reducing employment discrimination. ${ }^{130}$

But a regime in which hiring cases predominate may differ substantially from one in which discharge cases do. Such a shift in the nature of Title VII litigation may alter the deterrent effect of the statute in a way that generates some perverse consequences. Consider first an employer who is thinking about whether to hire a worker in a "protected" category. If the worker is hired, the employer will realize some additional output, which constitutes the benefit to the employer. Of course, the employer must also pay wages. If the employer feels animus towards women or minorities, he must in addition bear some psychological costs of associating with the worker. Absent any law prohibiting discrimination, then, the employer will make his hiring decision by comparing the value of the applicant's output if hired with the economic and psychological costs of hiring her. If the first quantity is larger than the second, the employer will decide to hire; otherwise, he will reject the applicant.

When discrimination is illegal, the employer must also take into account the potential costs of rejecting the applicant. These costs include the possible litigation costs if the applicant decides to sue and the damage award if the suit is successful, all weighted by their respective probabilities of occurrence.

The equation becomes more complicated when the possibility of discriminatory firing suits is introduced. A worker who is not hired in the first place is obviously in no position to bring a future firing suit. Thus, an employer must consider the increase in expected costs when he hires a female or minority worker, because some probability exists that the worker will be fired and will sue. Whether the increase in expected costs from hiring outweighs the savings realized by preventing a hiring discrimination suit depends on a number of factors. The greater the likelihood that the worker will ultimately be fired, and the higher the probability of a firing suit, the greater are the expected costs imposed by hiring. With the enormous increase in discharge cases, the probability that a worker will bring a discriminatory firing suit is now substantially higher than the probability that a worker will bring a failure to hire suit. Consequently, antidiscrimination laws may actually provide employers a (small) net disincentive to hire women and minorities. ${ }^{131}$

Table 9 provides a sensitivity analysis, which suggests that for a range of

130. Alfred W. Blumrosen, Black Employment and the LaW 4 (1971) (emphasis added) (citation omitted). Blumrosen was head of conciliation at the EEOC during its first three years and a key strategist in the early implementation of Title VII.

131. This was first suggested to us by Judge Posner. Richard A. Posner, The Efficiency and Efficacy of Title VII, 136 U. PA. L. REv. 513, 519 (1987). Since firing costs are incurred in the future, whereas the costs of failure to hire are borne immediately, the former must be discounted in computing the net effect of discrimination laws. This phenomenon operates generally: Restrictions on the ability of employers to fire workers may explain the greater caution of European employers in hiring new workers. 
Table 9

A Sensitivity Analysis of the Net Effects of Protection Against Hiring and Firing Discrimination on Employers' Incentives to Hire

Parameters

Expected Cost of Not Hiring
Model

1

.000006
176,000
.2
10,000
10,000
10
12
.07

$2 \quad 3$

$\begin{array}{rr}.000011 & .000004 \\ 88,000 & 25,000 \\ .3 & .4 \\ 15,000 & 20,000 \\ 15,000 & 20,000 \\ 10 & 10 \\ 12 & 12 \\ .24 & 1.20\end{array}$

45

$\begin{array}{rr}.0002 & .0008 \\ 5000 & 1250 \\ .5 & .6 \\ 25,000 & 25,000 \\ 25,000 & 25,000 \\ 10 & 10 \\ 24 & 24 \\ 8.46 & 36.61\end{array}$

Expected Cost of Firing at Time of Firing

9. Probability of suit for firing $(f)$

10. $1 / f$

11. Probability of winning suit (v)

12. Cost of defending suit $(C$ ) (dollars)

13. Cost of bringing suit $(C)$ (dollars)

14. Hourly wage $(w)$ (dollars)

15. Duration of unemployment $(D)$ (weeks)

16. Cost of firing $\left(E_{F}\right)$ (dollars)

\section{.000170} 5867

10,000

10,000

10

12

2.21

.000341
2933
.3
15,000
15,000
10
12
7.14

$\begin{array}{rrr}.00120 & .006 & .024 \\ 833 & 167 & 42 \\ .4 & .5 & .6 \\ 20,000 & 25,000 & 25,000 \\ 20,000 & 25,000 & 25,000 \\ 10 & 10 & 10 \\ 12 & 24 & 24 \\ 35.90 & 253.80 & 1098.24\end{array}$

Expected Cost of Firing at Time of Hiring

17. Line 16 discounted @ 4\% real interest .27 rate, with initial firing rate at $1 \%$, $.27 \quad .89$

4.47

31.59

136.69 declining by $1 / 40$ th each year for 40 years. ${ }^{\mathrm{a}}$

18. Line 16 discounted @ 4\% real interest $\quad .55$ rate, with initial firing rate at $2 \%$, declining by $1 / 40$ th each year for 40 years.

Net Values ${ }^{c}$

19. Net (line 8 - line 17)

20. Net (line 8 - line 18)

$\begin{array}{rrrrr}-.20 & -.65 & -3.27 & -23.13 & -100.08 \\ -.48 & -1.54 & -7.74 & -54.72 & -236.76\end{array}$

a. Implies that the probability that a newly hired worker will ultimately be fired is $18.1 \%$.

b. Implies that the probability that a newly hired worker will ultimately be fired is $33.1 \%$.

c. A negative number implies a disincentive to hire.

seemingly reasonable parameter values, the net effect of antidiscrimination litigation on hiring may now indeed be negative. As explained in more detail below, this ironic result stems from two facts: first, workers are much more likely to sue when fired from a job they already have than when their application for a new job is rejected; and second, the involuntary turnover rate is relatively high.

The calculations underlying the results in Table 9 are straightforward, if somewhat algebraically intricate. Take the expected costs of failing to hire a worker (line 8) as an example. This value is calculated as follows. Line 1 
gives the probability that, if not hired, a worker will sue; line 3 gives the probability that such a suit will be successful for the plaintiff. We can call these two probabilities $s$ and $v$, respectively. The costs of defending against the suit $\left(C_{d}\right.$, line 4$)$, if it is brought, must be paid even if the plaintiff loses. If the plaintiff wins, however, then the employer must pay not only his own costs $\left(C_{d}\right)$ but also the plaintiff's damages and legal costs $\left(C_{p}\right.$, line 5$)$, as well. Plaintiff's damages are calculated as the backpay award she would receive given an hourly wage ( $w$, line 6$)$ and a duration of unemployment $(D$, line 7$)$. Thus, the defendant's expected costs of not hiring a worker $\left(E_{N H}\right)$ can be expressed as

$$
E_{N H}=s \times\left[v \times\left(C_{d}+C_{p}+40 \times w \times D\right)+(1-v) \times C_{d}\right]{ }^{132}
$$

Line 8 then gives the value of this expression for the various combinations of parameter values shown in columns 1 through 5 . Think of this amount as the average (gross) cost to an employer of failing to hire a protected job applicant. As the table demonstrates, this cost is likely to be quite small. Even for the most extreme parameter values (column 5), the cost is less than $\$ 40$, and with more intermediate assumptions the cost falls dramatically.

As described earlier, however, this is only the gross cost of failure to hire. An applicant who is not hired is not in a position to bring a subsequent firing suit, and these cost savings must also be included in the employer's calculation of the effect of failing to hire an applicant. The table derives this calculation in two parts. Line 16 gives the first part of the calculation-the employer's expected costs of firing a worker at the date of firing. It is calculated analogously to line 8 . Note that the probability of suit by a fired worker is likely to be considerably higher than by a worker who was denied employment initially. Thus, the values in line 16 are larger than those in line 8.

Once the employer knows the costs associated both with failing to hire and with discharging a protected worker, the employer can then assess their relative magnitude. However, two adjustments must be applied to the expected firing costs: first, the probability that a newly hired worker will ultimately be fired is obviously less than one; and second, any firing will necessarily occur in the future and the attendant costs must be discounted at an appropriate rate. Table 9 makes the assumption that there is an initial probability of either 1 or 2 percent that a newly hired protected worker will be fired in the first year of employment and that this probability will fall each year for the next forty years. ${ }^{133}$ The table also employs a real discount rate of 4 percent. Lines 19 and 20 then show the net effect of the failure to hire a protected worker (which exposes the employer to a Title VII hiring action but avoids potential liability for any Title VII firing claim that ultimately

132. $40 \times w=$ the weekly wage, and $D$ measures the weekly duration of unemployment. Hence, $40 \times w \times D=$ backpay damages.

133. We assume that the probability that a newly hired worker will be fired falls uniformly to zero in 40 years. If the probability of firing is $2 \%$ in the first year, this implies that the probability that the employer will someday have to fire the worker is $33.1 \%$. With a $1 \%$ first-year firing rate, the probability that a newly hired worker will someday be fired is only $18.1 \%$. 
may be required). While there is obviously enormous uncertainty about the magnitude of the relevant variables (which explains why we offer such varying estimates in the five different models presented), under a wide array of assumptions there is a monetary advantage to an employer for rejecting the marginal protected applicant. In other words, under the current regime in which firing cases vastly outweigh hiring cases, Title VII may generate a net disincentive for employers to hire protected workers. ${ }^{134}$

The data in Table 9 assume that firing cases are six times more likely than hiring cases. Moreover, we assume that the average prospective worker files five job applications. These two assumptions imply that the likelihood of suit when an employer fires a protected applicant is thirty times greater than the likelihood of suit if the employer simply fails to hire the worker. Thus, the changing nature of employment discrimination litigation to primarily firing cases has had a profound effect on the monetary incentives that employers face. When hiring cases outnumbered firing cases by 50 percent, the likelihood of suit when an employer fired a protected applicant was only 3.3 times greater than the likelihood of suit if the employer simply failed to hire the worker. When we reestimated the figures in Table 9 using the 3.3 to 1 ratio instead of the 30 to 1 ratio, all of the numbers in lines 19 and 20 became positive. In other words, given the smaller likelihood of firing suits in the immediate aftermath of the passage of Title VII, the costs of failing to hire a protected worker outweighed the costs of possibly having to risk a firing lawsuit at some later time. The dramatic shift to firing cases has greatly increased the likelihood that Title VII will create a drag on the hiring of protected workers rather than the positive inducement it originally provided.

While the implications of Table 9 are intriguing, one should interpret this table with care. First, the table evaluates the effect of Title VII at the margin; presumably, firms have already spent considerable sums in avoiding Title VII litigation, for example, through affirmative action plans and validation of employment tests. ${ }^{135}$ These inframarginal precautionary expenditures partially explain both the low probability of a hiring suit and the low probability of plaintiff victory. Thus, the conclusion that Title VII's penalties are too small to have had any effect in the past would be grossly wrong. Any employer who failed to hire qualified blacks in the late 1960s or early 1970s would probably have faced a lawsuit. Moreover, the suit could

134. Note that if employers were to face a substantial expected firing cost burden by hiring protected workers, they would presumably reduce their hiring of such workers. This would cause the likelihood of litigation complaining of discriminatory failure to hire to rise. Therefore, firing and hiring costs will not be independent over the long term. The marginal expected hiring and firing costs would equalize in the absence of discrimination or productivity differentials.

135. For details on the kinds of programs employers have adopted to insulate themselves from employment discrimination lawsuits, see JAMES R. REDEKER, EMPLOYEe Discipline: PRACTICES and Procedures 16, 114-15 (1989); Alan F. Westin \& Alfred G. Feliu, Resolving EmPLOYMENT DispUTES Wirhout LITIGATION (1988). For a study of how and why firms change their internal equal employment policies, see Frank R. Dobbin, Lauren Edelman, John W. Meyer, W. Richard Scott \& Ann Swidler, The Expansion of Due Process in Organizations, in INSTITUtional Patterns and Organizations 71 (L. Zucker ed. 1988). 
well have been a class action. Thus, a total flouting of the law would have vastly escalated both the probability of a suit and the likely penalty. This explains why Title VII produced some important changes in employment practices during its first decade. ${ }^{136}$ The estimates do suggest, however, that antidiscrimination laws no longer provide employers with much additional incentive to avoid discriminatory conduct, especially in hiring. But that does not imply that eliminating the law entirely would increase total employment of blacks.

Table 9 should be viewed with caution for a second reason: The results assume that the probability a discharged worker will sue is constant regardless of the reasons the worker lost her job. The model does not distinguish between "individual-specific" and "macroeconomic" job terminations. But most workers who lose their jobs do so because of economic recession, not because of anything they might have done (for instance, absenteeism, poor job performance, or theft). ${ }^{137}$ In contrast, most litigation arises from individual-specific terminations. ${ }^{138}$ If most litigation arises from individuals who lost their jobs due to inadequate performance, and if such individuals constitute, say, one-fifth of all job losers, then the correct "probability of firing" figure in Table 9 should only be one-fifth as large as it is. This would naturally tend to reduce the disincentive effects of firing protection. ${ }^{139}$

\section{What Does the Law Protect?}

In 1968, Alfred Blumrosen began an article with the statement, "Discrimination in recruitment and hiring is the chief measurable evil against which the modern law of employment discrimination is directed." $140 \mathrm{By}$ the

136. Richard B. Freeman, Black Economic Progress After 1964: Who Has Gained and Why?, in StUdiES IN LABOR MARKETS 247, 269-83 (S. Rosen ed. 1981); Donohue \& Heckman, supra note 72.

137. The categories of individual-specific and macroeconomic firings are not completely discrete. For example, an employer who must lay off $10 \%$ of his work force due to a fall in demand may choose to lay off those who have high absenteeism rates or other individual-specific indicia of job performance. Alternatively, macroeconomic firings can generate employment discrimination litigation if, for example, an employer chooses to lay off on the basis of a seniority structure that incorporates past discrimination.

138. See James N. Dertouzos, Elaine Holland \& Patricia Ebener, The legal and ECONOMic CONSEQuences of Wrongful Termination 21 (1988) (Table 4). Dertouzos's study of wrongful termination suits in California found that $80 \%$ were filed by workers who had been terminated for inadequate performance, and only $20 \%$ by workers who lost their jobs due to exogenous economic factors. These data are based on the defendant's statement of why the discharge occurred, and should therefore be viewed cautiously. Id. Employers have a natural incentive to represent the plaintiff in as bad a light as possible in the context of a suit alleging unlawful discharge, so the $80 \%$ figure may overstate the true proportion of discharges based on inadequate performance.

139. For further discussion of the potentially conflicting effects of hiring versus firing protection on total employment, see Giuseppe Bertola, Job Security, Employment and Wages, 34 EuR. ECON. REV. 851 (1990).

140. Alfred W. Blumrosen, The Duty of Fair Recruitment Under the Civil Rights Act of 1964, 22 RUTGERS L. REV. 465 (1968). A further indication of the virtual absence of focus on discriminatory discharge as a part of employment discrimination efforts comes from a statement by one of the major forces in the development of antidiscrimination legislation. Irving Ives of New York was a principal author of the first state fair employment practice law (the Ives-Quinn bill), which was passed in 1945. 1945 N.Y. Laws 457. When Ives became a U.S. Senator, he introduced S. 984 in 
late 1980s, however, even if the chief evil had remained the same, the predominant object of complaint had become discriminatory firing rather than the failure to hire. We have previously noted the possibly pernicious deterrent effect of the shifting composition of private litigation. This shift to primarily discharge cases may also raise possible equity concerns, depending on one's conception of the current operation of the law. Accordingly, two related issues become important: First, to what extent has Title VII become a rent-protection law, that is, one used to reinforce existing gains by women and minorities, rather than to open new opportunities; and second, which groups of workers does the law protect, and against which kinds of discrimination?

\section{Antidiscrimination law as rent protection?}

In a world of zero unemployment, one way of characterizing Title VII and other federal antidiscrimination laws is as a means of protecting economic rents of currently employed workers. To see why, consider the definition of rents and its structural similarity to the way backpay awards are calculated in employment discrimination litigation.

The simplest definition of rents is the difference between a worker's current wage and her wage (or marginal product) in her next best alternative job. Consider an employment discrimination plaintiff who loses her old job (paying monthly wage $w$ ) and immediately finds a new one (at wage $w^{\prime}$ ). In this special case, the law defines damages as

$$
t \times \operatorname{Max}\left[0,\left(w-w^{\prime}\right)\right]
$$

where $t$ is the number of months between the plaintiff's firing and the date of the judgment on behalf of the plaintiff. The clear implication is that if the new job pays the same as, or more, than the old one, the law recognizes no damages. Generally it will be pointless for a plaintiff to bring a suit with a maximum value of zero. Therefore, all suits actually brought will be rentseeking by this definition.

Rents have traditionally received bad press in economics, and a law that "protects rents" would probably strike many as questionable or even illegitimate. Yet labor rents may be quite common in the employment marketplace-several studies have demonstrated that there are large and persistent differences in wages paid across industries for identical jobs. ${ }^{141}$ Nevertheless, conceiving of employment discrimination law as rent protection does

1947. Some of the language in this bill was later incorporated into the version of Title VII that was enacted. In his report on S. 984, Senator Ives wrote:

Contrary to the general impression, discrimination in employment is not confined to certain sections of the country, certain industries, or certain groups. . . .

Discrimination in employment is practiced by business, by government, and by labor unions. It is manifested by a refusal to hire, by a denial of in-service training or upgrading opportunity, by wage differentials, by the formation of auxiliary unions lacking the usual benefits of union membership, or by blanket exclusion from such membership.

Gold, supra note 55, at $\mathbf{5 7 0}$ (quoting Senator Ives in an unspecified report to the Senate). Ives did not even mention discrimination in firing.

141. E.g., Laurence F. Katz \& Lawrence H. Summers, Industry Rents: Evidence and Implica- 
raise an important equity issue. If Title VII and other federal antidiscrimination laws serve primarily to protect economic rents in existing jobs, they do not really protect the worst-off among the traditionally disadvantaged groups. Instead, they protect the relatively better-ofi among these groups-that is, those workers who already have jobs that generate rents, as opposed to those who have low-wage jobs or who are unemployed.

\section{Antidiscrimination law as transition protection.}

The thought that Title VII serves only to protect rents is clearly unjustified when we depart from the assumption of zero unemployment. The introduction of unemployment-which is clearly an important factor in plaintiff's calculations of whether or not to bring an employment discrimination suit-alters this picture substantially. ${ }^{142}$ Suppose a plaintiff loses her job, is unemployed for a number of months, and then finds a new job paying the same wage as her old one (so that $w^{\prime}=w$ ). While an argument could be made that such a worker was earning rents, ${ }^{143}$ an alternative view is frequently more realistic. Involuntary unemployment imposes transition costs on workers because they are forced to endure a period of zero wages until they secure comparable employment. This latter scenario views Title VII's antidiscrimination provisions as protecting the transition from one job to another. That is, the law makes an employer liable for the costs of searching for a new job when such a search is made necessary because of the employer's discriminatory firing of the plaintiff. ${ }^{144}$

tions, in BROOKINGS PAPERS ON ECONOMIC ACTIVITY 209 (1989); Alan B. Kreuger \& Lawrence H. Summers, Efficiency Wages and the Inter-Industry Wage Structure, 56 EcoNOMETRICA 259 (1988).

142. For an analysis of the effect of unemployment on employment discrimination litigation, see notes 14-17 supra and accompanying text.

143. The argument that the worker is earning rents is that her next best alternative is to secure comparable employment only after a spell of unemployment. One method of calculating these rents would be to subtract the value of lost wages (during the period for which the plaintiff was out of work) from her lifetime wages in the new job. A comparison of the lifetime wages in the old and new jobs would then show that, although the wages in the two jobs are nominally equal, the net lifetime wage in the new job is actually lower than the previous wage because the worker had to wait for some length of time at zero wage (unemployment) in order to get the new job. This would imply that the worker was earning rents in her previous job.

Whether the difference in net wages indicates rents in the previous job turns on the nature of the job search (waiting period) for the new job. If the time spent waiting for the new job is seen as voluntary -in the sense that the worker screened various jobs and rejected some in the hopes of finding a better-paying offer-then the correct calculation of rents would require subtracting this waiting time from the value of the second job. For models of unemployment as a queue for jobs with rents, see John H. Harris \& Michael P. Todaro, Migration, Unemployment and Development: A TwoSector Analysis, 60 AM. ECON. REv. 126, 127 (1970); see also Kreuger \& Summers, supra note 141, at 280. If, by contrast, the unemployment is involuntary, then the waiting time is really a function of macroeconomic frictions and has little to do with the existence of rents. Economists have devoted considerable theoretical and empirical effort to the study of job searches and their relationship to unemployment. For a recent survey, see Dale T. Mortensen, Job Search and Labor Market Analysis, in 2 HANDBOOK OF LABOR ECONOMICS 849 (O. Ashenfelter \& R. Layard eds. 1986). In general, it strains credulity to believe that all unemployment is the result of optimal job searching behavior by individuals.

144. Note that for most workers, unemployment insurance will cover at least some part of the costs of a job search. The circuit courts have split over whether an employee's backpay award should be reduced by the amount the employee receives in unemployment compensation. Compare, 
Furthermore, discharge may be a signal to future employers that the discharged worker is defective. This may cause such workers to drop down to lower-paying, less desirable jobs upon being discharged. Such a consequence may well be appropriate if the discharge is justified. But this economic burden will be inappropriately inflicted on a worker who is discharged for purely discriminatory reasons, since future employers will not be readily able to distinguish legitimate from discriminatory discharges. Title VII is certainly designed to compensate for such losses, which is far different from pure rent protection. Of course, one of the problems of any compensatory scheme is that the effort to protect legitimate interests will at times lead to an award of damages to those who are less deserving, such as those earning rents. But this is quite different from asserting that all beneficiaries of Title VII awards are merely protecting their rents.

\section{The lack of protection against discrimination on the job.}

A striking fact that emerges from the ABF survey is that plaintiffs in employment discrimination litigation rarely sue their current employers. In fact, only 10 percent of suits by non-government employees are brought by plaintiffs who were working for the defendant at the time the suit was filed. Most employment discrimination plaintiffs are discharged workers, while a few are workers who were never hired.

Consideration of how damages are calculated in employment discrimination suits reveals why so few plaintiffs are current employees. Damages under Title VII are limited to backpay (plus injunctive relief). A worker who is harassed on the job, for example, may be able to prove liability but will have a difficult time showing cognizable damages. Even someone who was passed over for promotion will only receive the difference between her current salary and the salary she would have earned had she been promoted.

In considering whether to sue her current employer, moreover, a potential plaintiff must weigh the costs of suit against these meager benefits. The possibility of deliberate retaliation by one's employer, or simply a souring of

e.g., Brown v. A.J. Gerrard Mfg. Co., 715 F.2d 1549 (11th Cir. 1983) and Kauffman v. Sidereal Corp., 695 F.2d 343 (9th Cir. 1982) (unemployment insurance is not deductible from the award) with EEOC v. Enterprise Ass'n Steamfitters Local No. 638, 542 F.2d 579 (2d Cir. 1976) (deducting employment compensation receipts), cert. denied, 430 U.S. 911 (1977); see also P. Cox, supra note 55, at 23 (1987); Special Project, Back Pay in Employment Discrimination Cases, 35 VAND. L. Rev. 893,1009 (1982).

Neither approach is optimal. Allowing employees to collect full backpay on top of their unemployment compensation confers windfall gains on plaintiffs; on the other hand, deducting unemployment compensation from the damage award received by a worker provides windfall gains to employers. The optimal solution would make the employer liable for the full backpay award, but reimburse out of this award the unemployment compensation amount to the state. At least two states, Colorado and Califomia, follow such a procedure. Their unemployment laws require a prevailing plaintiff to repay the state unemployment fund out of an award of backpay. See, e.g., Colorado Employment Security Act, CoLo. REv. STAT. § 8-73-110(2) (1973).

The issue is analogous to the question of whether damages for nonpecuniary losses in tort should be paid to the victim, to the government, or not paid at all. See John J. Donohue, The Law and Economics of Tort Law: The Profound Revolution, 102 HARV. L. REV. 1047 (1989); see generally K. HYLtoN, supra note 128. 
the employment relationship, militates against litigation in this context. In most cases, litigation is a viable option only when the employment relationship has been broken off (or never existed). ${ }^{145}$

We conclude from these observations of how employment discrimination law works that if we want to protect workers from on-the-job discrimination, alternatives to the current form of private litigation must be found. These might include mandating changes in firms' internal administrative machinery, ${ }^{146}$ pressure by public agencies such as the Office of Federal Contract Compliance Program (OFCCP) or the EEOC, or the allowance of punitive and compensatory damages. Again, however, the tradeoffs discussed above must be noted. More protection for workers on the job may make it more difficult for similarly situated workers to find a job in the first place. Therefore, any strengthening of protection for currently employed workers needs to be undertaken with caution.

\section{What Has Title VII Wrought?}

We are left with a paradox: Over twenty times more employment discrimination cases were filed in FY 1989 than in FY 1970, while the amount of bias against women and minorities and exclusions from jobs and occupations has almost certainly fallen. If there were so many fewer suits twentyfive years ago, how can we argue that federal antidiscrimination policy was actually more effective then than it is now? The answer is fourfold. First, the flagrant and obvious violations of the pre-Title VII era-systematic refusal to hire women or minorities for certain jobs, gross disparities in pay for identical jobs, segregated work place facilities-were much more likely to produce plaintiff victories than the subtler and less-frequent forms of discrimination practiced today. ${ }^{147}$ A rational employer in 1965 need not have waited until he was actually sued to change his employment practices. Thus, the mere threat of litigation would probably have induced an employer to change his behavior. But this is increasingly less true.

Second, we note that class action suits are well-suited to attacking gross violations of the law, as many discriminators learned. When gross violations are eliminated, the possibilities for bringing class action suits should fall. ${ }^{148}$ This is precisely what has happened, as we demonstrated earlier.

Third, the vast preponderance of the rise in litigation has come from allegations of discriminatory firing. Such suits actually provide employers with a disincentive-perhaps even a net disincentive-to hire minorities and

145. Federal employees, who are protected by Civil Service regulations, are much more likely to sue while still employed at their old jobs.

146. For examples, see the case studies discussed in J. REDEKER, supra note 135, or in A. WESTIN \& A. FeliU, supra note 135.

147. As Donohue \& Heckman, supra note 72, at 9, point out, almost all of the improvement in black men's relative wages between 1965 and the present has occurred in the South, where segregation, pay disparities and other forms of discrimination were practiced most grossly.

148. Since most class action suits focus on discrimination in hiring rather than firing, the results in Figure 8 are consistent with the relative decline in significance of hiring cases. 
women. Thus, we would expect less of an improvement per suit now than in the earlier phase.

Finally, we have ignored the other components of the federal antidiscrimination effort, including affirmative action programs for federal contractors. These programs constitute an important complement to private litigation under Title VII and other statutes. Indeed, if the thrust of this paper is correct, such programs are especially important in encouraging hiring, given that private litigation may no longer have a strong pro-hiring effect.

In summary, the effects of Title VII have changed from the opening up of access to jobs for traditional victims of discrimination to the protection of those who already have jobs. We may now have a sort of implicit tort of wrongful discharge-absent the potential for punitive damages-for virtually all workers except white males under age 40 . In large measure, this result has not come about through direct changes in the law itself or the ways that courts have interpreted it. Rather, the nature of the protection provided by antidiscrimination legislation has been shaped by the behavior of plaintiffs, defendants, and the economy at large. 
Heinonline -- 43 Stan. L. Rev. 1034 1990-1991 